Article

\title{
Use of Cultural Heritage for Place Branding in Educational Projects: The Case of Smederevo and Golubac Fortresses on the Danube
}

\author{
Uroš Radosavljević ${ }^{1, *(1)}$ and Irena Kuletin Ćulafić ${ }^{2}$ (i) \\ 1 University of Belgrade-Faculty of Architecture, Department of Urbanism, Bulevar kralja Aleksandra 73/II, \\ 11000 Belgrade, Serbia \\ 2 University of Belgrade-Faculty of Architecture, Department of Architecture, Bulevar kralja Aleksandra 73/II, \\ 11000 Belgrade, Serbia; kuletin@arh.bg.ac.rs \\ * Correspondence: yros@arh.bg.ac.rs
}

Received: 1 August 2019; Accepted: 18 September 2019; Published: 24 September 2019

check for updates

\begin{abstract}
Medieval fortresses represent an important tangible heritage of a nation's culture and a valuable development asset for a particular destination on which its place-branding strategy for tourism could be built upon. Traditionally in Serbia, heritage protection and conservation have been mainly concentrated on the tangible aspects of cultural sites and monuments. Nevertheless, with the advent of urban heritage integration in the local sustainable development processes and place-branding strategies, a greater appreciation of the spirit of the place and its intangible components, as well as the need to adapt it to local contexts with more participatory forms of heritage planning, have started to emerge. A wide range of stakeholders brought the involvement and participation of both the local government and community members, including residents, as an indispensable element of the protection actions and broader urban development policies. The paper aims to validate the correlation between both intangible and tangible cultural heritage and its contemporary use for place branding and tourism development. In doing so, we have employed the case study method on the two fortresses on the Danube in Serbia to show the ways in which local stakeholders have mobilized their forces in cooperation with the university to use their cultural heritage assets for tourism and more extensive sustainable territorial development. We have found that despite new inclusive forms of governance, which is attracting the attention of planning and heritage practitioners in Serbia, the contemporary approach of integrative protection and the intangible aspects of cultural heritage are still not fully utilized. For this reason, in this study, we consider methods based on environmental aesthetics approaches to cultural heritage that point out the significant inclusion of immaterial intangible cultural heritage in an unbreakable bond with material tangible heritage. The most remarkable result of our research is that while a vast number of stakeholders with local knowledge and sense of the spirit of the place have been involved in the planning process, intangible aspects of the analyzed heritage cases are present in educational projects, and are only partially present if it comes to implementation. This clearly demonstrates that the focus on tangible aspects and spatial interventions of the place branding of cultural heritage is still dominant in Serbia, despite acknowledgment of the economic and social aspects of sustainability in the planning phase in educational projects.
\end{abstract}

Keywords: tangible and intangible cultural heritage; place branding; educational projects; the Danube River; Smederevo Fortress; Golubac Fortress; cultural tourism; inclusive forms of governance and heritage planning 


\section{Introduction}

Cultural heritage is the cornerstone of local, regional, national, and European identity [1]. It is a common value and a shared asset that is not only an integral part of the cultural sector but also a significant element and incentive for the development of tourism and other industries. Cultural heritage includes tangible-material, physical, and intangible-immaterial, dynamic, living heritage elements that are inextricably correlated. As a whole, tangible and intangible cultural heritage are in a complex connection depending on the natural heritage and environment [2]. Cultural reality represents a dynamic set of living and active processes, whereby it comprises tangible and intangible heritage to be considered as a whole. In this sense, cultural heritage does not only represent tangible monuments and collections of objects, but also the intangible traditions and living expressions inherited from our ancestors. Intangible cultural heritage relates to the practices, representations, expressions, knowledge, and skills-as well as the instruments, objects, artifacts, and cultural spaces associated therewith - that communities, groups, and in some cases individuals recognize as part of their cultural heritage [2].

The Athens Charter [3] was first to propose the idea of a common world heritage. It was followed by the Venice Charterand the creation of the International Council on Monuments and Sites ICOMOS [4], and finally the World Heritage Convention [5]. Summarizing the catastrophic consequences of the two world wars, the comprehension of world heritage and idea for its safeguarding, conservation, and protection were strongly oriented on material aspects of heritage: built structures, great works of art and architecture, archeological and natural sites. This Decartian view on culture, characteristic of Western philosophical and cultural thinking, remained dominant until the late 20th century. In the late 1980s, challenging questions were raised in terms of intangible cultural heritage, as a new modality of cultural heritage existence [6].

Moreover, awareness of the importance, value, and the need for the preservation of intangible cultural heritage is in the focus of the world and socially concerned goals of the humanity in the new millennium. Taking into consideration the challenges of the 21st century in terms of globalization, social transformations, frequent threats from terrorism and armed conflicts, disappearance and destruction of the intangible cultural heritage, and the lack of resources for its safeguarding, the United Nations Educational, Scientific and Cultural Organization (UNESCO) drafted and adopted the Convention for the Safeguarding of the Intangible Cultural Heritage in 2003 [2] with the aim of establishing normative instruments. Therefore, the UNESCO Convention is an area of particular interest for our research, because of the understanding of cultural heritage, the methodology of work, and the instruments it uses to protect the cultural heritage, which has changed very much in the last decades. The adopted conventions, declarations, and instrumental legal acts emphasize the importance of an integrated approach in addressing the problems related to the conservation, protection, use, and transmission of cultural heritage. To this end, the cooperation of various participants from different disciplines and domains of activity is emphasized as one of the most critical conditions in strengthening social identity and diversity, and in the achievement of local, regional, and international cultural heritage goals, as a key factor for cultural sustainability and sustainable development in general [1]. An integrated approach to the protection of cultural heritage implies smart, sustainable, and inclusive growth, and therefore it can be a powerful driver for local and regional development on a national level, which is aimed at promoting sustainable, responsible, and high-quality cultural tourism [1].

Regarding tourism management, one of the most essential elements is to identify the potential of a particular cultural heritage to manage tourism in an innovative, cost-effective, and at the same time sustainable way. Although Serbia has based its tourism strategy primarily on the material (tangible) cultural elements for decades, parts of rich Serbian intangible heritage have been in focus in the past few years, and are still at the very beginning of their perceptions and potentials in terms of drawing the attraction of domestic and foreign tourists [7]. One of the reasons for the reduced utilization of intangible cultural resources in tourism in Serbia is that the Serbian cultural and scientific public is still at the stage of research processes focused mainly on the cooperation of various participants solely 
within the cultural sector. In a few cases, collaboration with the Tourist Organization of Serbia (TOS) was also carried out, but actual intangible cultural values have not yet found their full expression for modernizing the tourist offer in Serbia and complementing it through an unbreakable bond with material and physical tangible heritage.

Cultural tourism is one of the oldest forms of tourism. As early as medieval times, there were various religious pilgrimages: annual cultural events that represented the motive of tourist trips. According to the definition that was adopted by the World Tourism Organization (UNWTO) at the 22nd Session of the General Assembly held in Chengdu in China, cultural tourism is a type of tourism activity in which the visitor's essential motivation is to learn, discover, experience, and consume the tangible and intangible cultural attractions or products of a specific tourism destination [8]. Cultural heritage tourism includes the cultural, historical, and natural experiences of the places and products. In that sense, we can speak of different cultural attractions or products, such as the intellectual, spiritual, and emotional features of a society that encompasses art and architecture, historical and cultural heritage, culinary heritage, literature, music, creative industries, and the living cultures with their lifestyles, value systems, beliefs, and traditions [8].

According to Richards [9], tourists' motivation for cultural tourism can be a culture of consumerism, low and high desire for cultural experiences, the tendency for learning, satisfaction, and revisiting intentions. By highlighting the interrelations between tangible and intangible cultural heritage, cultural tourism today should be understood in an inclusive spirit as a means of communication between different stakeholders that reinforce authentic values of places and the social culture of people. In that sense, the interpretation of cultural heritage is not only a set of historical information collected in the form of written texts about individual monuments. Today, tourists are active participants who seek experiences and gather knowledge in a personally involved and active way.

Besides cultural tourism, local governments have been employing place-branding strategies during the last few decades for improving attractiveness and image in order to create additional value in place [10], and thus achieve advantages in competition with other cities in entrepreneurial shifts in urban governance, as Harvey [11] and Jessop [12] have highlighted. According to Boisen, Terlouw, Groote, and Couwenberg [13], place branding has gone through transformations from (1) place promotion - which focuses on generating favorable communication; (2) place marketing — which deals with balancing supply and demand; and finally, (3) place branding-which is mainly about creating, sustaining, and shaping a favorable place identity. Therefore, central to place branding are the issues of value creation and identification. As Kapferer suggests [14], a brand can be perceived as something that gives meaning and creates value to the product while defining its identity. Furthermore, Ashworth [15] underlines that place branding deals with discovering or creating uniqueness, which can differentiate a specific place from the others in order to gain competitive brand value. Regarding the practical utilization of place-branding strategies on the local urban level, the setup we used is practically the same as the one proposed by Ashworth [15]. He claims that the three main local planning instruments are: (1) personality association, in which places associate themselves with an individual from history, the arts, or even mythology; (2) the visual qualities of buildings and urban design, which could involve flagship buildings, signature urban design, and even whole districts; and, (3) event hallmarking, in which the place organizes cultural or other events for a wider recognition and specific brand associations. A challenging area in the field of place-branding processes has been suggested by Govers [16], who considers that the shape and substance of places are produced by residents. Therefore, the brand of a place should be built on the sense of place and identity of the local population and other social actors. Furthermore, the interplay between place branding and identity, as recognized by Karavatzis and Hatch [17], is a dialogue between stakeholders in the dynamic interaction of internal definitions of identity and external views of the image of the place, and arising from the interaction between the two. Therefore, Karavatzis and Hatch [17] underline that place branding and identity consists of four main features: expressing the place's cultural understandings, mirroring impressions and expectations, reflecting and adding new meanings and symbols, and leaving an impact on others. 
The concepts of cultural tourism and place branding represent contemporary challenges for local governments in the entrepreneurial context in regeneration processes. One challenge is how to disclose the uniqueness of a particular place and yet achieve a competitive advantage. The other challenge is how to present local identities, touristic assets, and cultural attractions to tourists and make them a part of the extraordinary experiences.

That is why it is of great importance that the development of cultural tourism strategies at heritage sites should involve collaboration and teamwork with various stakeholders regarding the heritage assets and its possible adaptive reuse [18]. This is in line with the discursive inclusivity in the participatory governance of cities and the communicative-collaborative planning model, which focuses on the communication between all stakeholders as a tool for reshaping political powers $[19,20]$. In the communicative-collaborative model, according to Innes [21], various interests should take part in the communication for coming to a consensus concerning goals for the planning process. Healey [20] stresses that reaching consensus about future actions through discussion is vital for achieving mutual understanding. Therefore, the knowledge and information obtained through such a process are not scientifically known in advance, and are created in relation with the specific opportunities found in the local context. Subject-subject relation is understood here as a process in which all actors define a problem together and, as a result, they become experts as well [22]. Therefore, involving stakeholders in a participative way requires not only planning experts with political skills for negotiation, but institutions and forums as well. Additionally, the process of collaboration between higher educational institutions and municipalities, along with various representatives from public institutions, can have an impact on building capacity at the local level [23].

Case studies of Smederevo and Golubac fortresses represent notable examples of how cultural and natural heritage elements can be a source of aesthetic experiences. The aesthetic level of communication is a conscious, cultural layer that transmits ideas within a society, epoch, or group of people [24]. Accordingly, it is possible to use the environmental aesthetic approach as the basis for support for the creation of inclusive touristic strategies. Environmental aesthetics is based on the principles of sustainability and appreciation of natural, human, and human-influenced environments [25]. It explores the aesthetic positions of balancing relationships between people and their environment-both natural and human - through the exploitation of resources and technological development that does not disturb the natural, sociological, and economic system [26].

The significance of environmental aesthetics for cultural heritage tourism is found in experiences that are related to the emotional uniqueness that tourists feel during the consumption of some cultural asset, but at the same time, environmental aesthetics is a constructive factor of the spirit of the place [27]. The authentic spirit of the place of the Smederevo and Golubac fortresses not only represents the potential driving force of tourism in this area, but also contributes to the rehabilitation and renewal of forgotten knowledge of heritage and its promotion through modern branding techniques and methods of cultural management. In this sense, environmental aesthetics are of paramount importance for place branding, since they explain the theoretical and practical sense of place, atmosphere, and the cultural components of certain places.

Environmental aesthetics emphasize the most important fact of the environmental approach: natural and human or human-influenced environments do not exist separately; they are in a mutual relationship and coexist as such [28]. The environmental aesthetics approach in urban design and architecture stresses the appreciation, preservation, restoration, maintenance, improvement, and conservation of all environments-natural, urban, and social-as one of the most current conditions of its ethical, aesthetic, and humanistic achievement [29].

Furthermore, as Cooper, Brady, Steen, and Bryce [30] claim, the interpretation of cultural heritage includes spiritual and aesthetic evaluations of nature that are an anthropogenic vision of natural beauty. In compliance with the environmental aesthetics principles, Harrison [31] argues that the natural and cultural heritage of national parks cannot be separated. Divisions between nature and culture are invented by academic experts and sociopolitical institutions. For example, Dai people who live in 
villages in China do not make nature-culture difference in their everyday lives [32]. In order to feel the aesthetic emotions of the sublime, they witness nature and culture as complementary and inseparable. This is a cross-cultural perspective that is aligned with the multicultural vision of world heritage, which favors the great importance of nature-culture interlinks [33].

In the case of cultural tourism, we can agree with Arnold Berleant, who developed the idea of aesthetic engagement. He considers that environmental perception is in the quality of engagement of our senses in perception - that is, participation in environmental experience [34]. Likewise, according to Böhme, the atmosphere in architecture is created through a complex relation of the object-formal and informal characteristics of architecture-and the subject-audience, users-that makes the perception and is brought into a certain emotional state [35]. According to the European Union (EU) Commission Regulation, natural heritage is often crucial for the shaping of artistic and cultural heritage. Heritage conservation should consequently combine natural heritage with cultural heritage [36].

Cultural heritage tourism could also be seen as environmental nature tourism, where the tourism industry supports the conservation and safeguarding principles of natural, built, and intangible heritage [37]. On the other hand, aesthetic beauty and design have an important role in tourist destinations, and could be used in order to renew weak relationships between culture, heritage, inhabitants, and the environment [38]. In addition to economic and social benefits, cultural tourism could have a very positive impact on environmental aesthetic experiences and cultural heritage safeguarding. As Daniela Angelina Jelinčić claims [39], psychological and neuroscientific approaches to the creation of aesthetical experiences results in powerful traces in tourist memories. Cultural heritage tourism could also be interpreted as creative tourism that particularly highlights intangible heritage values through collaboration, exchange, and learning from local inhabitants, craftsmen, and artisans [40]. Following the idea of a creative project, cultural heritage tourism could be of great significance for the survival of traditional skills, knowledge, and practices.

Having lost their original military purpose in the 19th century, the Smederevo and Golubac fortresses are nowadays living evidence of history and social culture, created as a product of the synergistic action between man and nature. These fortresses form part of the urban, natural, and sociocultural landscape that represents the evolutionary development of a society that has inhabited the region of the Danube River throughout history. Therefore, they represent an important element in the formation of the cultural identity of the Smederevo and Golubac regions, and, at a higher level, they are an essential element of the historical and national Serbian identity [41]. The Smederevo and Golubac fortresses have been under protection since 1979 as a national property of exceptional importance. The Smederevo fortress was included in the UNESCO World Heritage Tentative List in 2010 for possible nomination. This paper presents how the cultural potentials of the Smederevo and Golubac fortresses and intangible heritage in their respective territories were used for the creation of place-branding strategies and urban design projects exercised through the educational projects in cooperation between the University of Belgrade-Faculty of Architecture and local governments in Serbia.

Consequently, through the cases presented in this paper, we have tried to answer the main question that arises and highlights the difference between tangible and intangible cultural heritage, referring to Harrison and Rose [42]: How can intangible assets be adequately protected when they exist only in minds, traditions, stories, and ephemeral practices? We offered an answer that encompassed cultural, environmental, social, and economic values through case studies of the Smederevo and Golubac fortresses by treating their tangible and intangible resources as a unique amalgam. In accordance with the principles of UNESCO and the ICOMOS framework, we suggest that rigid procedures that separate and accentuate division between tangible and intangible characteristics of the world cultural heritage should be neglected. More often than not, the intangible, non-material aspect of culture cannot be separated from the material and physical heritage. Case studies of the Smederevo and Golubac fortresses underline our thesis that both tangible and intangible heritage establish cultural identity. 


\section{Research Methods and Materials}

The general methodology and research design used in this paper are based on the case study method with the examples of Smederevo and Golubac fortresses on the Danube River in Serbia. The research design strategy for the cases of Golubac and Smederevo was to include different stakeholders' needs and analyze multiple levels of collaboration and communication processes between the local community and municipality representatives, cultural institutions, touristic stakeholders, experts, and professionals through educational projects. The main goal of such an approach was that the research findings could contribute to the policy debate, as argued by Farthing [43], in a way that research within the planning discipline frames different conceptions and perspectives of the social world, including the recognition of values that shape the research process, as well as knowledge as socially constructed, and the discipline of planning as political. Framed in such a way, the results of the research are intended to highlight possible research directions in the field of cultural tourism development and intangible safeguarding practices, and be used in the future cultural, touristic, environmental, and branding development of the Lower Danube region in practice.

In the introductory part of the paper, we have used theoretical research and a literature review from different disciplines of culture, tourism, governance, and planning in order to better understand and further deepen the relations among specific subfields of cultural heritage, environmental aesthetics, tourism management, cultural tourism, place branding, and planning models and concepts. The method of content analysis was used in different research phases. It included analysis of the various documentation types-conventions, laws, reports, plans, literature, documents, photo documentation, and educational projects-in order to enable the key analytical elements and arrange case studies.

We came to the conclusion that the best method for our investigation of the use of cultural heritage for place branding in educational projects was the case study method. Our reasons for using the case study method bears a close resemblance to Flyvbjergs' [44] justification of the benefits of the case study qualitative method research option, in that it can be an outstanding selection for real-life situations, since it can test views in relation to phenomena as they disclose in practice. Additionally, according to Yin [45], case studies are an approach that is useful for more in-depth and more detailed investigation when it is necessary to answer how and why questions emphasizing the reliability of the theoretical and practical framework primarily based on the context analysis of a distinctive situation: in our case, the two fortresses on the Danube River.

The case study method has proved to be suitable for this type of research, since it focuses on describing the historical development phases of cultural tangible and intangible heritage of case studies in question, their economic, environmental, and social context, as well as the processes of cooperation between academia and local governments, communities, and other stakeholders in educational projects. The two cases of the Golubac and Smederevo fortresses are examined as an empirical phenomenon in their whole, regarding the interrelations of their cultural, economic, touristic, environmental, and historical characteristics. The unit of analysis that has been chosen as the basis for the case studies includes a review of the educational projects realized at the University of Belgrade-Faculty of Architecture in 2008-2010 for the Golubac case, and in 2018 for the Smederevo case. Educational projects offer a case-study database and theoretical-empirical platform that include documents, work notes, interviews, design and research materials, narratives and observations, etc.

The main research methods for the case study research were a review of primary and secondary sources-conventions, laws, reports, plans, literature, documents, photo documentation, educational projects-site investigations that included a field visit, and interviews with key stakeholders involved in the projects. A total of nine in-depth, semi-structured interviews were conducted with the representatives from the municipalities in question, their tourist organizations, and the Republic Institute for the Protection of Cultural Heritage. Additionally, the information was also collected through photographic surveys during site investigations-four field visits per investigated site-and through the acquisition of maps, statistical data, and existing projects from the Municipality of Golubac, the City of Smederevo, and the Republic Institute for the Protection of Cultural Heritage. 
In case studies, we have analyzed how the cultural resources of these fortresses and intangible heritage from their hinterland are used in cooperation with the University of Belgrade-Faculty of Architecture as a strategic instrument in educational projects with the purpose of creating effective place-branding strategies for the contemporary sustainable tourism development of the Middle and Lower Danube regions. The examples are given in the paper to present how the cooperation has taken place and the directions in which the future collaboration among universities, cultural heritage institutions, governmental and non-governmental organizations, local communities, and local authorities could continue. The paper highlights the significant results achieved by involving local communities in the processes of gathering experiences and requirements that are useful for the creation of place-branding strategies and projects to achieve the most efficient development of tourism in this area that respects the principles of safeguarding cultural heritage and thus sustainable development. By providing opportunities for the local community to actively participate in the formation of the planning strategies in the educational projects in question, one of the most important goals of the Intangible Cultural Heritage Convention [2] has been fulfilled, which is to provide attention and responsiveness to the communities whose cultural traditions are being safeguarded. This is a so-called "bottom-up" participatory process [46].

\section{Results}

\subsection{Danube Region and Eastern Serbia as a Tourist Attraction}

In order to clarify the problem of cultural heritage and branding, we will illustrate the example of two medieval fortresses in the lower Danube region (Figure 1). This region extends in Eastern Serbia as one of the emerging clusters [47] along the left bank of the Danube River, on its course between Veliko Gradište and the mouth of the Timok River, about $200 \mathrm{~km}$ long.

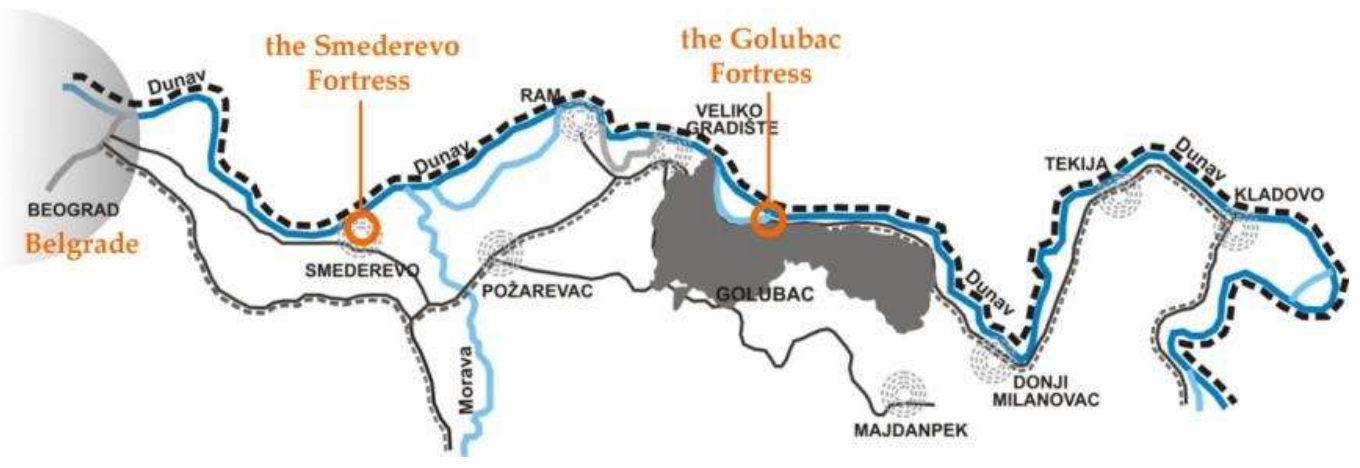

Figure 1. Location of the two case studies in the lower Danube region in Serbia (author: Uroš Radosavljević).

The Danube, as the second longest river in Europe, has merged and separated cultures and nations throughout history. Since ancient times, people have built their first habitats near the river, irrigated crops, engaged in fishing, and at the same time, the river was the route of transport, communication, and the first trade route. Even today, the Danube represents one of the most important natural and cultural resources of Serbia. It is the place where cultures and civilizations met, mingled, and formed. Therefore, along the Danube through Serbia, in the length of $588 \mathrm{~km}-20.3 \%$ of its total length - the most important cities and human creations were formed, which testifies to the synergy of natural and cultural heritage. In addition to the historically significant cities of Belgrade, Novi Sad, Sremski Karlovci, Zemun, Smederevo, and Golubac, along the Danube, the first European cultures were formed, which are today witnessed by prehistoric settlements Vinča and Lepenski Vir. Along the Danube, the border of the Roman Empire (the Danubian Limes) extends as a system of fortifications built for 550 years from the time of Trajan to Justinian I, which had a defensive function of protection from the 
northern tribes. In its entirety, the Danube is a unique natural environment whose most distinctive feature is the Djerdap National Park—the pearl of the Balkans regarding its particular biodiversity.

This area is linked in different ways. A specific historical development, a favorable Djerdap climate, and a complex network of gorges, canyons, and deep bays make this area a unique European reserve of tertiary flora, vegetation, and fauna. The distinct diversity of geomorphologic forms, among which the Iron Gate gorge is particularly distinguished, as well as the altitude of $50-800 \mathrm{~m}$ mark this area as having great tourist potential. Likewise, the great diversity of cultural and historical monuments, archaeological sites, and traditional folk architecture, as well as the specific way of life and local intangible culture, represent a significant potential for the development of eco, hunting, cultural, and rural tourism, as well as the economic development of the territory. On the other hand, the lower Danube region and the region of Eastern Serbia represents an area that is economically underdeveloped in relation to the rest of the Republic of Serbia, with a value of $14.6 \%$ of the regional gross domestic product (GDP) compared to the national GDP of Serbia and 2.7 times lower GDP compared to the one of the city of Belgrade as the capital of the Republic. These potentials have been recognized at the national level as an opportunity to attract investment into this region, and have been formulated within the Master Plan for the development of the lower Danube region [48]. Additionally, the Danube corridor is recognized as a strategic European tourist resource in the Strategy for the Development of Tourism of the Republic of Serbia [49], which gives three possible approaches to tourism development. In the second identified approach, the Danube corridor is recognized as a strategic European tourist resource due to its geostrategic position. Primary strategic potentials for tourism development are cultural and archeological heritage, positive approach to tourism development from the citizens, geostrategic location, and vast natural resources. On the contrary, the main obstacles for tourist development are a lack of national and regional visions for tourism development; that Serbia has not yet been recognized as a tourist destination; lack of tourist infrastructure-roads, accommodation, information, etc. Consequently, the strategic development of tourism in Eastern Serbia is recognized as the future tourist cluster based on the territorial identity and its rich cultural, archeological, and natural potential, as well as its specific cuisine.

\subsection{Case Study: Golubac Fortress}

\subsubsection{The Golubac Fortress-Tangible and Intangible Heritage}

The Golubac Fortress was built on the geostrategic position at the entrance to Djerdap Canyon-Iron Gates-on a high and steep mountain cliff that rises along the Danube River, with the best view of the whole surroundings (Figure 2). It is presumed that the fortress was built in the 14th century on the earlier military-defensive ancient Roman fortification, whose visible remains are at the base and in the immediate surroundings of the fortress. The Golubac Fortress is an entirely military fortification without a suburban settlement outside the walls of the fortification. Due to its undeniable favorable geostrategic position during the 15th century, the Golubac Fortress was besieged by Serbs, Hungarians, and Turks, under whose authority it remained until 1867, when the final liberation of Serbia from the Ottoman authority occurred. The Golubac Fortress was proclaimed a cultural monument of exceptional importance in 1979, under the protection of the Institute for the Protection of Cultural Monuments, while the application for the UNESCO Tentative List has not yet been implemented.

In addition to its historical and cultural value, the ecological and economic values of the Golubac Fortress are essential for the development of tourism. The Golubac Fortress is located at the very beginning of the Djerdap Canyon where the Danube breaks through the Carpathian Mountains and captures scenes of incredible beauty. Djerdap Canyon is the most massive fissure in Europe, and its $300-\mathrm{m}$ vertical cliff height represents a rare natural phenomenon. More than half of the Golubac municipality is occupied by the Djerdap National Park, which is the largest national park in Serbia, with rare and endemic species of plant and animal life [50]. The remains of the Roman Limes are on 
the territory of the Golubac Municipality, and they were included in the UNESCO World Heritage Tentative List in 2015 within the frontiers of the Roman Empire [51].

The Golubac Fortress is an extraordinary example in which material built historical heritage is an intrinsic part of the natural heritage. The pristine nature surrounding the Golubac Fortress represents a great potential for the development of cultural tourism and sustainable ecotourism in Serbia. Other than the Golubac Fortress, which is the generator of tangible and intangible heritage in the surrounding area, there are other numerous assets of natural heritage: walking paths throughout the Djerdap National Park, rivers, cascades, waterfalls, and gorges. A special curiosity is represented by salaš farms in the Golubac area, which are rural properties representing the symbiosis of tangible and intangible cultural heritage. These farms were created in the collaboration of man with nature, witnessed by the folk architecture, the way of life, and their customs and traditions lasting for 300 years-they are very appealing as a specific tourist attraction and have been increasingly attracting tourists [52]. Another exciting form of the intangible cultural heritage of the Golubac area is the sociocultural phenomenon of Rusalka, featuring a woman who each year falls into a trance on the Pentecost religious holiday, which is a ritual symbol associated with the ancient Slavic pagan beliefs that were eventually mixed with the Christian ones [53,54].

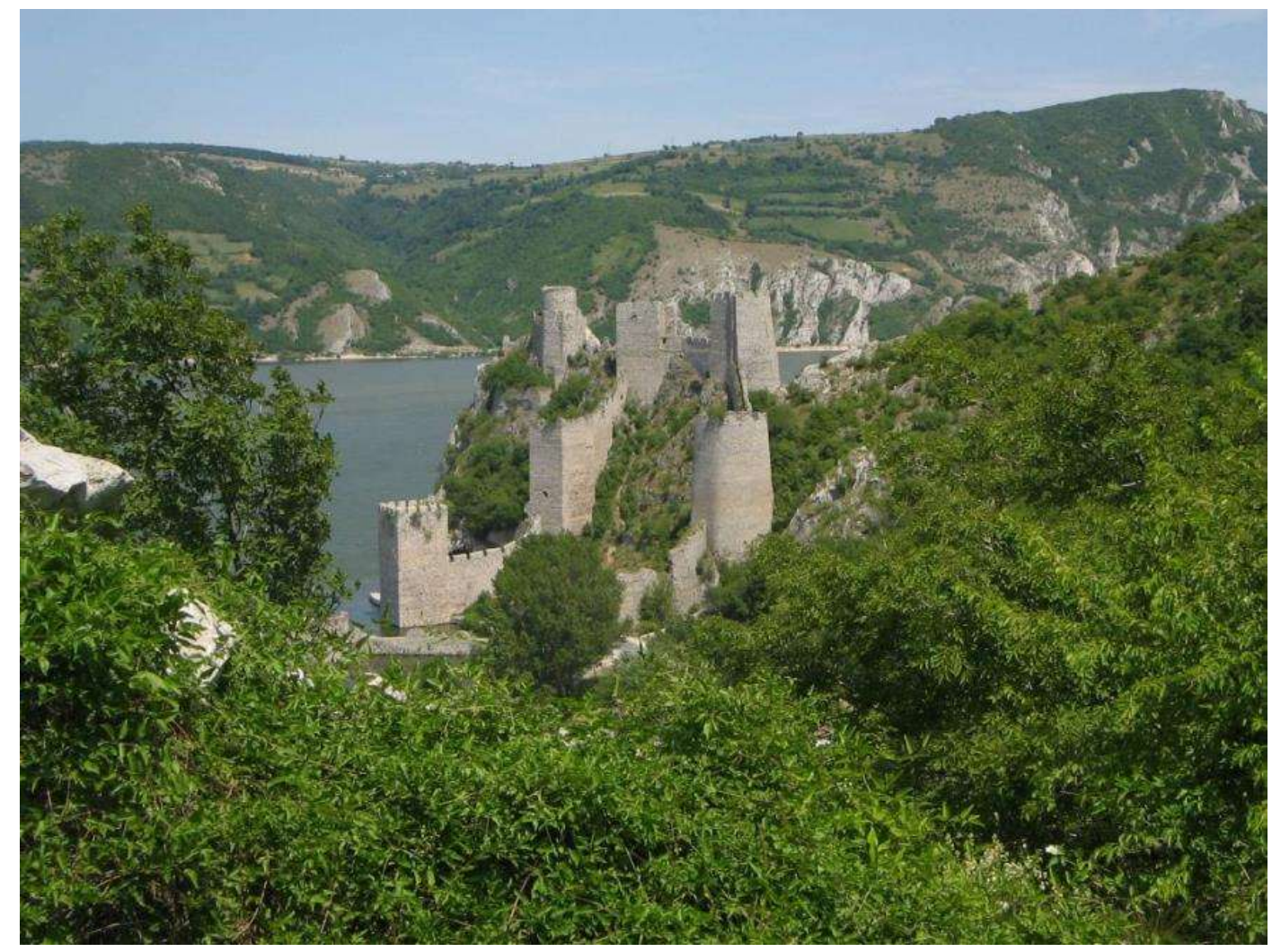

Figure 2. The Golubac Fortress, the Danube River, and the Djerdap National Park (author: Uroš Radosavljević).

However, until recently, the Golubac Fortress itself has not been regulated and maintained for years, and it was even closed for visitors for a long time due to security reasons after the accidental fall of a pupil from the wall due to the lack of equipment, fences, and generally poor structural condition of the fortress [55]. Coupled with the problematic accessibility, part of the regional Djerdap carriageway has been passing through the Golubac Fortress through the tunnels, which made the fortress relatively dangerous. Freight transport has been mainly affecting the safety of tourists and pedestrians, but also affecting the visual, ecological, and memorial integrity of the fortress as well. There have also been 
problems with the lack of compatible tourist activities and tourist information about the fortress and its surroundings-both in the nearby city of Golubac and in the vicinity of the fortress.

\subsubsection{Educational Master Project Tourist Valorization of the Golubac Fortress}

Initiation of the Project Tourist Valorization of the Golubac Fortress

The educational research project Tourist valorization of the Golubac Fortress was realized as a form of cooperation between the University of Belgrade-Faculty of Architecture and the German Technical Corporation Agency (GTZ) during the academic year 2008-2009 [56]. At the same time, the municipality of Golubac has participated in a wider GTZ program - the municipal economic development in the Danube region from 2007 to 2012. The main goal of the GTZ program was to facilitate partnerships for the sustainable socioeconomic development of eastern Serbia through active participation of local, regional, and national government representatives in Serbia.

The municipality of Golubac has recognized that the fortress is one of the most important cultural and heritage sites on which the future tourism offer of the municipality would be based. Nevertheless, the municipality has not come up with a planned solution for future tourism development, and they have chosen to use the fortress as a pilot project in the above-mentioned GTZ program. The GTZ goal of active stakeholders' participation was in line with the participatory paradigm, which has been at the time of conducting the research of paramount importance for the educational master project. The professional and academic debate has been searching for new planning directions since the beginning of the 2000s [57]. Similarly, this shift has been moving from the traditional planning procedures in a bureaucratic institutional milieu toward the communicative-collaborative model, both in practice and education of planning and urban design in Serbia.

Precisely in this setting, and under those professional and educational circumstances, the project was realized as a master thesis research and project Opportunities of valorization of the medieval Golubac fortress as a tourist center, led by the academic mentoring team from the Faculty of Architecture in Belgrade.

\section{The Proposed Themes for Heritage Interpretation}

The mentoring team came up with the idea of exploring the topic of a sustainable approach to the regeneration of environmentally valuable assets, and it has been the main driving principle of the project and the applied methodology. Consequently, it was important to establish a balance between the protection and development of local identities, tangible and intangible heritage. The issues addressed by the educational projects relate to a sustainable approach to the activation of the tourist potential of cultural and historical heritage by involving the local community, stakeholders, and institutions at regional and national levels.

Several themes for the heritage interpretation have been considered in the project, such as the specific socioeconomic context of the Golubac municipality, as well as the natural environment of the Golubac Fortress, its historical development, and environmental features. Specific interpretive elements intended to be used in the proposed solutions of educational projects were tourist attractions as a mix of natural and built environment, different ways of accessing the fortress, tourist accommodation and services in and around the fortress, reconstruction, adaptive reuse, and activation of authentic walls, towers, and rooms of the fortress, ethno-tourism for nature and healthy living, and finally the information center and promotional activities in the vicinity of the fortress. In the following part of this section, we will present specific student projects.

\section{Student Projects for Tourist Valorization of the Golubac Fortress}

The first field visit followed in March 2009 when the research team from the Faculty of Architecture with 10 students visited and explored the most important heritage and tourist sites and the development potential for the municipality of Golubac: the Djerdap National Park as the most important natural 
heritage, the Danube River, the Golubac Fortress, and pedestrian trails from the fortress to the town of Golubac.

The creation of the tourism development policy of the municipality of Golubac project has researched the possibilities for the creation of a tourism development policy for the municipality of Golubac. The main research hypotheses were that although there are many cultural and natural assets on its territory, the municipality of Golubac has no organized, designed, and planned cultural and touristic offer, due to the lack of intersectoral cooperation and multidisciplinary education system for cultural tourism. The research aimed to properly utilize the growing popularity of travel as a tourist activity related to culture and to promote the cultural identity of Golubac with the Golubac Fortress, the Djerdap National Park, the Djerdap Canyon, and the Danube River. The main goal was to produce a common tourism policy for the creation of new local and regional cultural identities. A new place brand was envisioned to be created by using the potentials of cultural and historical assets for the development of cultural tourism in the municipality of Golubac and the lower Danube region based on the future vision of space. The project uses three elements of the tourist destination classification as the starting premise of the policy: (1) attraction, as a mix of different elements of natural attractiveness-climate, flora, fauna, geographical position, etc., and social attractiveness-cultural-historical heritage, anthropogenic factors, etc.; (2) accessibility - both geographic and economic distance; and (3) conditions for tourist stay -all the elements that make a tourist offer in terms of accommodation, services, food, entertainment, recreation, etc. Extensive analysis of the existing legislative and regulatory framework in the field of culture, tourism, and urban development is given as well as the current cultural and natural manifestations and tourist assets, problems, risks, and SWOT analyses-a technique to identify strengths, weaknesses, opportunities, and threats.

The project envisions possible tourism forms and activities, such as transit, cultural, nautical, excursion, and rural tourism. Additionally, assessment of the institutional framework for the project management and implementation, tourism and social trends, and officially planned projects and plans for the tourism development of the municipality of Golubac has been carried out. Equally important are the envisioned instruments of the strategic planning process that have been suggested with respect to creating a tourism development policy of the municipality of Golubac, which should use sustainable strategic projects to provide the sustainability and quality of the territory (Figure 3).

The adaptive reuse, regeneration, and tourist activation of the Golubac Fortress project has researched the history and military development of the fortress and its surroundings and its strategic location along the Danube from the Roman up to medieval times. The research included legends about the name of the fortified border city and its function for the control of water flows, with the defense based on a system of towers and walls. Additional analyses and evaluation of the current physical situation of the fortress have been performed to enable different forms of protection. The goal was to support the tourist utilization of the fortress and create a basis for the cultural and historical tourism. In order to do so, the introduction of new uses and programs into the fortress and its surroundings is necessary to increase the attractiveness of the fortress, change the image, and eventually create a place brand.

Moreover, conceptual proposals have been made for ethno-tourism - compatible with cultural and historical tourism - that would entail the revitalization of the traditional heritage architecture and its activation. Ethno tourists can get acquainted with both the medieval and the current traditions and culture of this region, and additionally enjoy the content oriented toward nature and healthy living. The research has been done with and for the local community to involve them in the process of planning of the territory, making them an integral part of the tourist offer, thus contributing to the spirit of the place. Additional principles for the development of local identities in the project represent intangible heritage safeguarding in the form of storytelling as an essential part of the place uniqueness, and the most pleasant way to convey oral traditions.

Adaptive reuse and activation of the Golubac Fortress has been envisioned in phases, depending on the available resources. In the first conservation phase, securing fall-prone parts and preserving 
authentic walls to ensure the accessibility to the fortress is planned. In the second phase, a partial reconstruction of individual towers and rooms is envisioned, so that they can be used as museum and gallery spaces, a gift shop, and a bookstore that would be supplied with literary works on the fortress and Golubac (Figure 4).

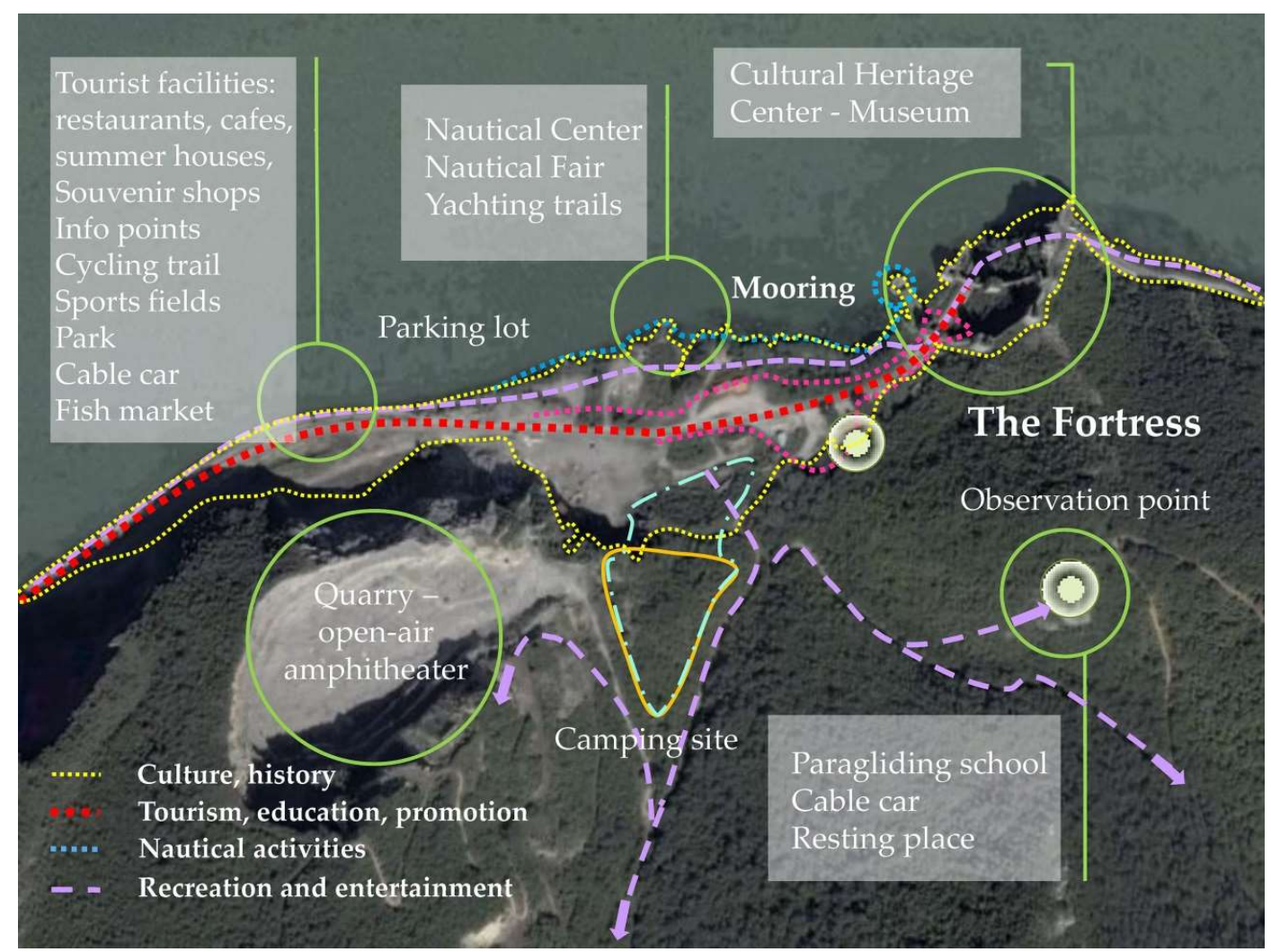

Figure 3. Strategic sustainable projects for the tourism development of the Golubac Fortress (authors: students Jelena Čangalović and Danica Živadinović).

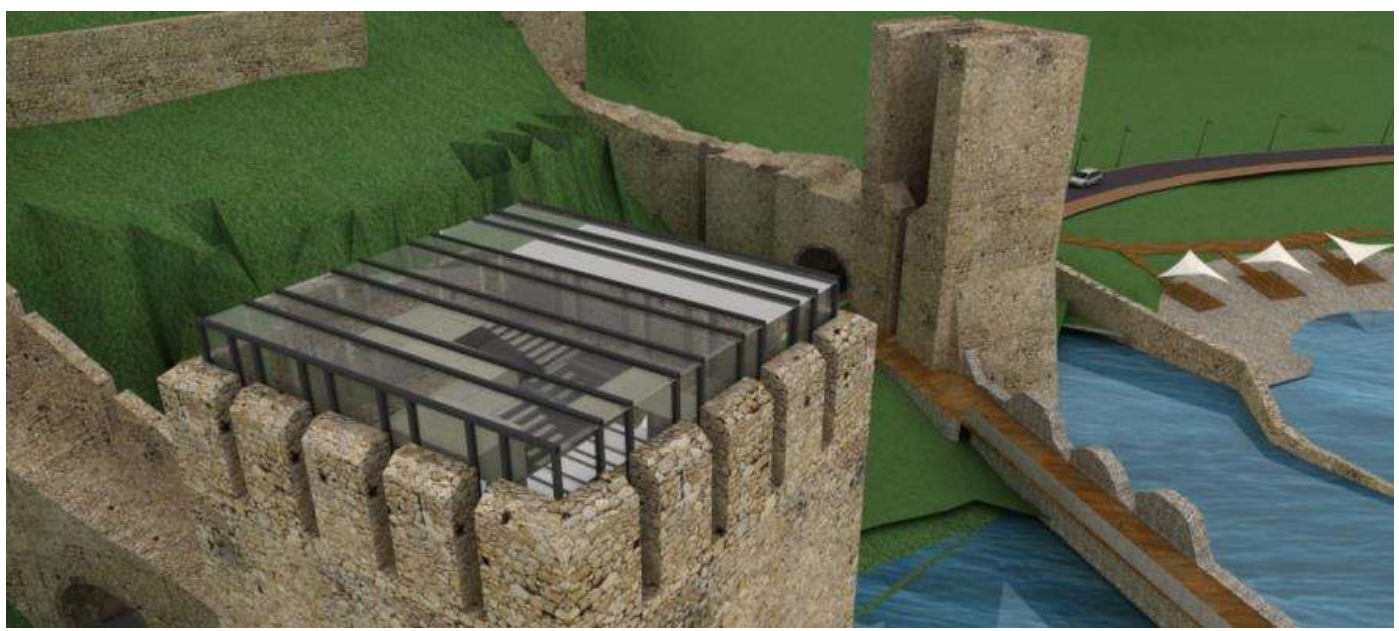

Figure 4. Reconstruction of the tower into the exhibition space (authors: students Stefan Drašković, Sandra Đokić, and Jovana Pavić).

Compatible tourist activities in the vicinity of the fortress are envisioned in this phase, such as restaurants, a tourist information center, marinas for small tourist boats, accommodation facilities-which can include ethno houses, as well as supporting elements-parking spaces, and toilets, which would all complete the tourist offer (Figure 5). The offer is further enriched with different 
workshops presenting traditional crafts and medieval weapons and clothing. In the third revitalization phase, a complete reconstruction is planned in order to raise the level of attractiveness of the entire site. That would allow repositioning of the fortress into a network with existing or planned similar sites along the Danube and the formation of a tourist tour in the lower Danube area, thus creating a unique tourist offer.

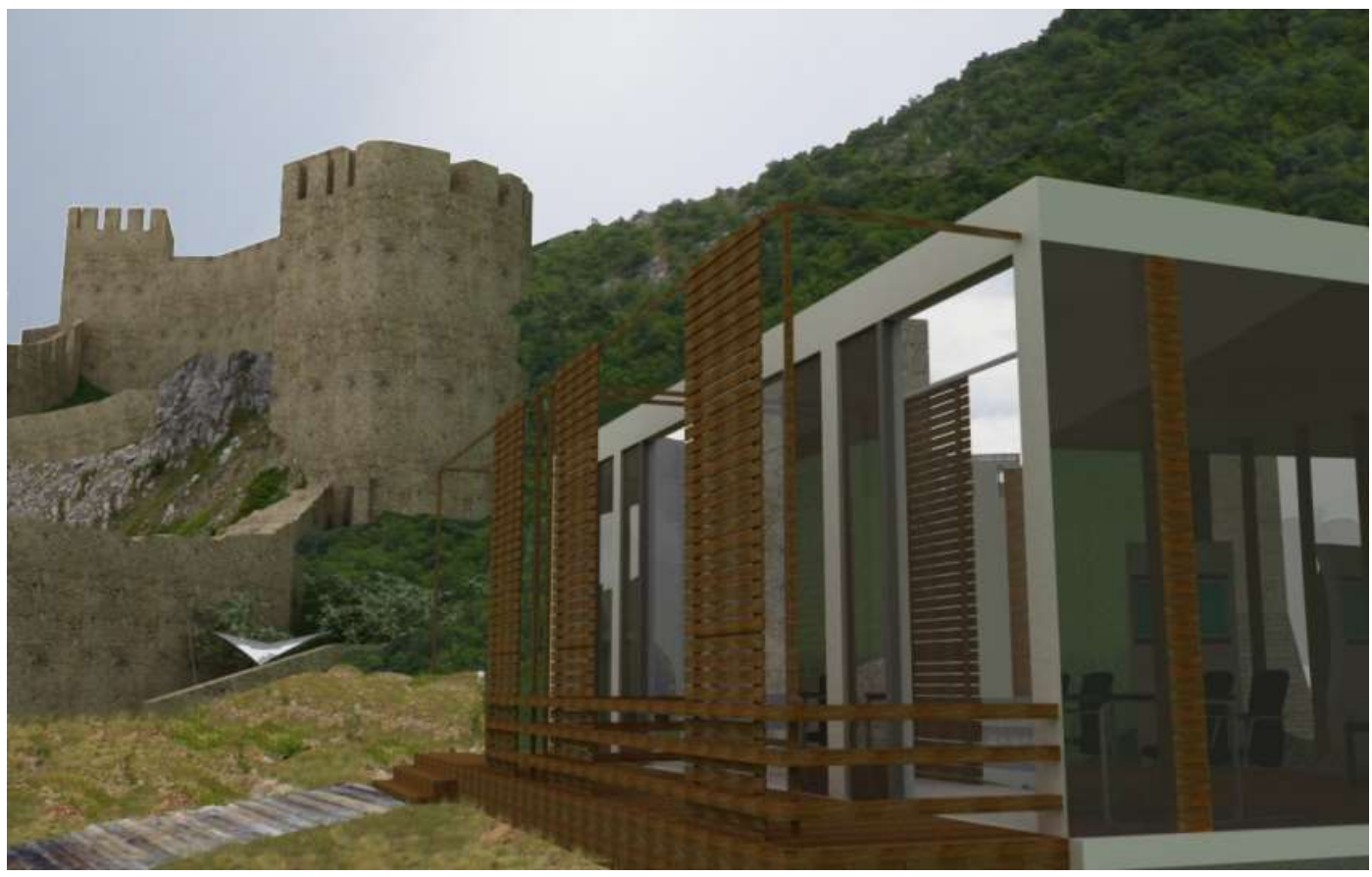

Figure 5. The tourist information center in the vicinity of the Golubac Fortress (authors: students Stefan Drašković, Sandra Đokić, and Jovana Pavić).

The final appearance and look of the fortress is designed with all the amenities for functioning as a tourist center, and as such, represents the visual, aesthetic, and iconic elements and focus for visitors. In this sense, the facilities in the immediate surroundings of the fortress must not impair the aesthetic integrity of the fortress itself, and have to be carefully designed. The same goes for the natural amenity of the Djerdap National Park in the vicinity, which should be used as a kind of attraction and the scenery for the fortress, and would complement its environmental aesthetics.

\subsubsection{Results of the Educational Project for the Revitalization of the Golubac Fortress}

A students' educational project and research have been used as the basis for the Plan of Tourist Valorization of the Golubac Fortress [58] done by the University of Belgrade-Faculty of Architecture team and adopted in 2010 by the municipality of Golubac. The plan consists of two separate parts: (1) baseline research about the strengths, weaknesses, opportunities, and threats, and (2) 11 measures that will enable tourist activation of the Golubac Fortress in a sustainable manner. Additionally, the main aim of the plan was to activate the tourism potential of the fortress in a short period.

The overall objective of the project has been to set up preconditions for the revitalization of the Golubac Fortress and create conditions for tourism development. Furthermore, several specific objectives have been designated. One was to define the future development of this tourist destination and redesign the fortress and its surroundings so that it can be accessible to tourists in a significantly more intensive way than it is now. Thus, the model for the optimal utilization of this facility has been selected, with particular emphasis on the services, activities, and events that live up to tourists' expectations. The aim was to maximally preserve the environment and cultural heritage, with constant improvement of the quality of services for tourists. The last—but not the least-important objective was to set up a framework for taking further activities in the tourist utilization of the fortress, meaning that 
a planned and systematic approach to advancing the tourist offer will bring about faster development of the tourist destination.

It was expected that by improving the conditions and the frame for the development of tourism in the municipality of Golubac, a basis would be created for accessing investments. Investing local or foreign capital in the field of tourism infrastructure and tourism in general would as a consequence have greater engagement of the local workforce and increased revenue from tourism, which is directly in function of the local economic development and thus contributes to sustainable development.

The first workshop was held in April 2009 in the Town hall of Golubac, when the preliminary results of the research of the potentials for sustainable development of tourism in the municipality of Golubac and the revalorization and reactivation of the fortress were presented (Figure 6).

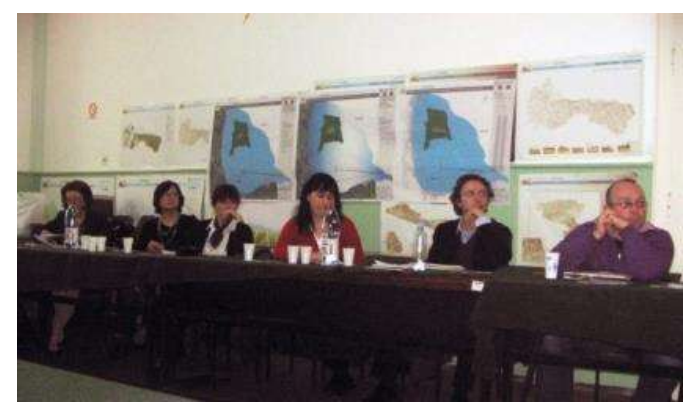

(a)

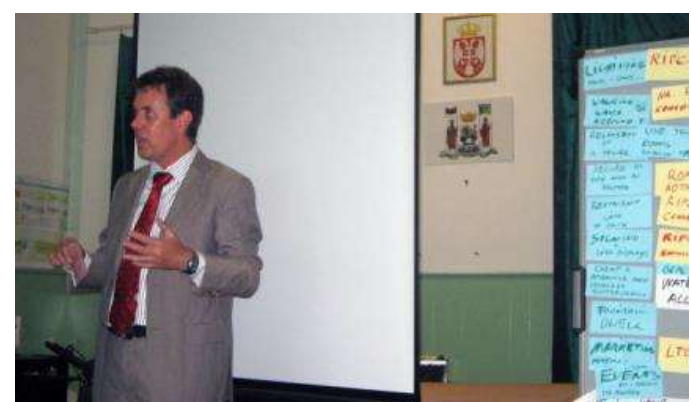

(b)

Figure 6. (a) Presentation of the preliminary results for sustainable development of the fortress (author: Uroš Radosavljević); (b) Workshop charrette in the municipality of Golubac (author: Uroš Radosavljević).

The structure and objectives of the project, expected outputs, timeframe, and participatory process phases have been discussed, structured, and prioritized with relevant stakeholders at national, regional, and local levels, regarding their responsibilities, willingness to participate, and resources for the adaptive tourist reuse of the fortress. Three ministries participated at the national level一the Ministry of Economy and Regional Development and its Department of Tourism, the Ministry of Culture, and the Ministry of National Investment Plan (NIP)—alongside the Tourist Organization of Serbia (TOS), and the Republic Institute for the Protection of Cultural Heritage (RIPCH); the regional-level organizations were the the Djerdap National Park and RARIS-Regional Development Agency Eastern Serbia; and at the local level, there were representatives of the municipality of Golubac and its Department of Local Economic Development (LED), the Tourist Organization of Golubac (TOG), several private tourist businesses, representatives of the local catering association, and GTZ representatives [58]. Another form of stakeholder inclusion was provided through individual encounters in the process of project measures elaboration to receive feedback from them. A series of meetings have been held with the representatives of the Republic Institute for the Protection of Cultural Monuments, the Ministry of Economy and Regional Development, and their Department of Tourism (Figure 7).

The second workshop was held in September 2009, when elaborated measures were presented and discussed with local stakeholders in the municipality of Golubac-the mayor, the representatives from relevant public companies, the representative from the tourist organization of Golubac, GTZ representatives, and the consulting team. Their suggestions and recommendations were incorporated in the measures and small projects for the regeneration of the fortress [58].

The plan provides a strategic framework for using sustainable, small measures and projects that can be implemented independently or incrementally in a short time, and the flexible way according to available financial, organizational, and legislative aspects in order to activate the regeneration process of the fortress [58]. The following small measures or projects were developed for the improvement of management capacities at the local level; for producing statutory plans; for mobility improvement; for the stability and reconstruction of the fortress; for the visual identity of the fortress; for promotion; and, for the tourist infrastructure in the surroundings of the fortress (Figure 8). 


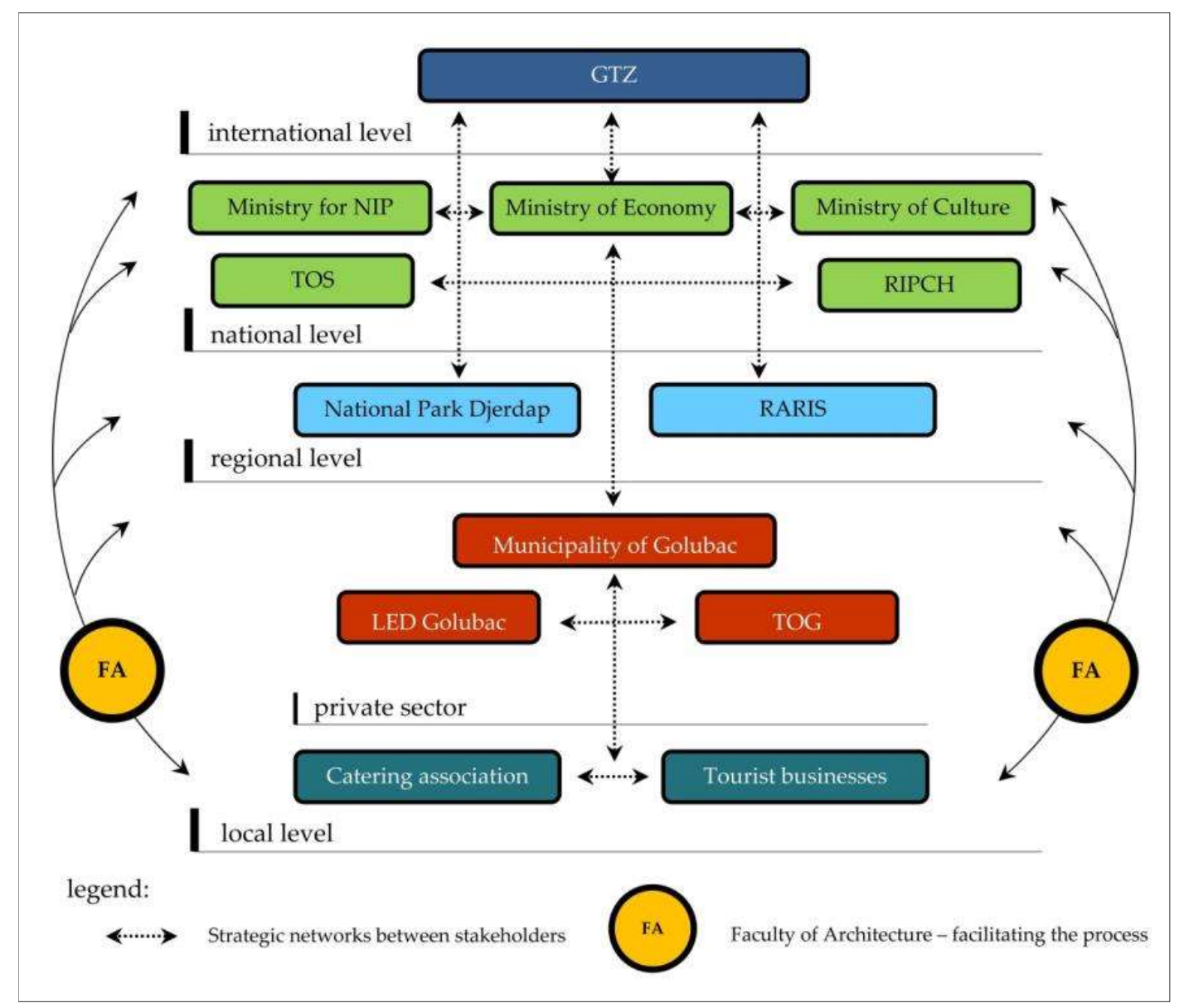

Figure 7. Strategic networks between stakeholders in Golubac [55].

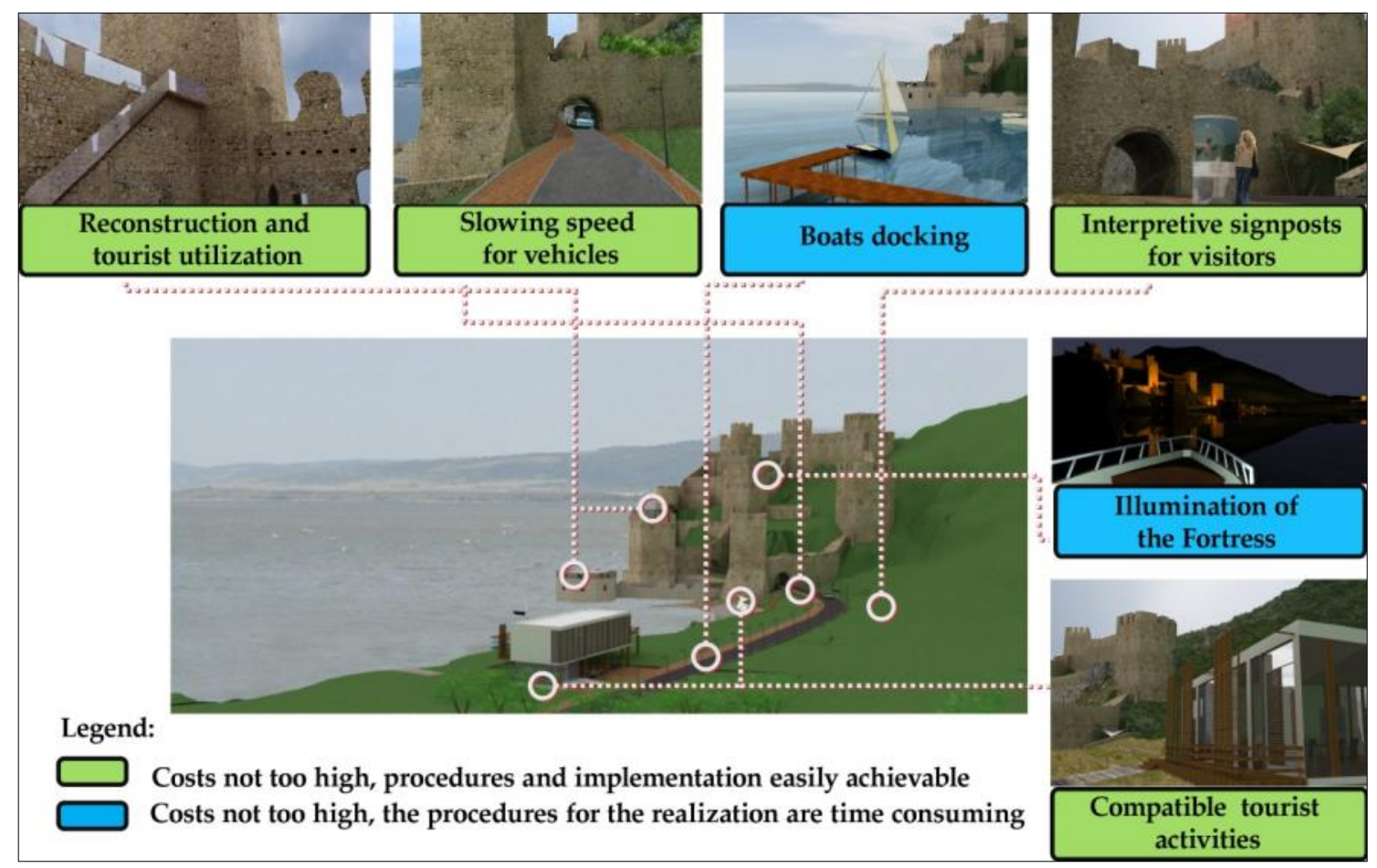

Figure 8. Spatial distribution of small measures and projects for the regeneration of the Golubac Fortress (authors: Radosavljević, Mrđenović, Pavić, and Krell). 
The realization of all small projects would lead to the improvement of the image of the fortress, thus shaping favorable place identity. Additionally, the plan treats different dimensions of sustainability, including the protection and promotion of the cultural heritage and identity of the place, the development of social capital in an inclusive manner, and economic development sensitive to the natural resources in the surrounding Danube River and the Djerdap National park.

After the municipality adopted the Plan in 2010, it received $€ 6.5$ million from the EU to invest in the revitalization of the fortress. The reconstruction of the fortress started in 2014, and the focus during the implementation of the plan was on the physical reconstruction and preservation aspects of the fortress. Consequently, all the small yet achievable projects for enhancing tourist offerings and compatible activities from the plan have not been implemented in the vicinity of the fortress. In the spring of 2019, the reconstruction of Golubac Fortress was completed, and it is possible to visit the fortress. Nevertheless, since the fortress has been activated minimally and tourists can visit and pass by it, its economic and tourism potential has still not been fully accomplished.

\subsection{Case Study: Smederevo Fortresses}

\subsubsection{The Smederevo Fortress-Tangible and Intangible Heritage}

There are almost 40 fortresses and remains of former fortifications in Serbia. Smederevo represents one of the largest and most well-preserved examples of medieval military fortifications in southeastern Europe. Smederevo Fortress is distinguished by its outstanding and universal value, due to its historical and cultural significance (Figure 9). It was a fortified castle with a ruler's court and urban settlement, which constitute an essential example of the development of medieval urban centers. Smederevo Fortress has a distinctive location since it is a unique example of a medieval flatland fortress type located along the river banks of the Danube River and the Jezava River. Smederevo Fortress was built between 1428-1439 by Despot Djuradj Branković, who was trying to preserve the sovereignty of the Serbian state due to the constant threat of the Ottomans in the south and the Hungarians in the north. The goal of Djuradj was to build a practically unassailable fortification as soon as possible. That is why the construction of Smederevo is well remembered in the folk tradition, especially in the folk poems highlighting the suffering of the Serbian people who built Smederevo. Smederevo is also mentioned in poems as a white, unassailable city of unsurpassed beauty. Since its establishment to the present day, Smederevo has had a very rich intangible cultural heritage that constitutes an inseparable symbiosis with the material heritage of the fortress itself.

The colossal appearance of the Smederevo fortress-with 25 towers that are 20 meters high and four meters wide, with double ramparts and bounded by water on all sides-is still striking and amazing today. The fortress consists of the Small Town where Djuradj's court was located, and the Big Town where the church, residential, and other buildings were located. Although only four bifora windows were preserved from the court of Despot Djuradj, written sources testify to the beauty, richness, and luxury of the interior decoration of the palace.

Despite the unstable political circumstances at the court of Djuradj Branković, cultural life flourished, and literature, art, court music, crafts, trade and economy, primarily mining, were developed. Djuradj's revenues from mining were so high that foreign visitors wrote that Serbia was lying on gold and silver. In particular, the Novo Brdo mine was at that time the most significant and richest mine in the Balkans [59]. This natural wealth of Serbia attracted numerous invasive attempts. After several years, Smederevo fell under the Ottoman rule in 1459 for almost four centuries, which was at the same time the end of the existence of the Serbian Despotate.

Smederevo Fortress suffered great destruction during the first and second world wars. Conservation and restoration works have been performed on several occasions up to the present time. Smederevo Fortress is preserved in its integral form, and it represents the culmination of Serbian medieval military architecture. It is a traditional human settlement, a specific land-use that represents Serbian culture and human interactions with the environment [60]. 
In modern times, Smederevo Fortress has had an active cultural and artistic role for decades. It is a place of social interaction where numerous cultural and artistic events, concerts, festivals, and ceremonies are held. Smederevo Fortress is a symbol of Smederevo and the creator of the city's identity. The fortress is part of the city's urban landscape, the natural landscape of the Danube, and the cultural landscape that involves people and their customs in the Smederevo region. However, the construction of the railroad between the fortress and the city of Smederevo in 1884 separated the city from the Danube River and the fortress.

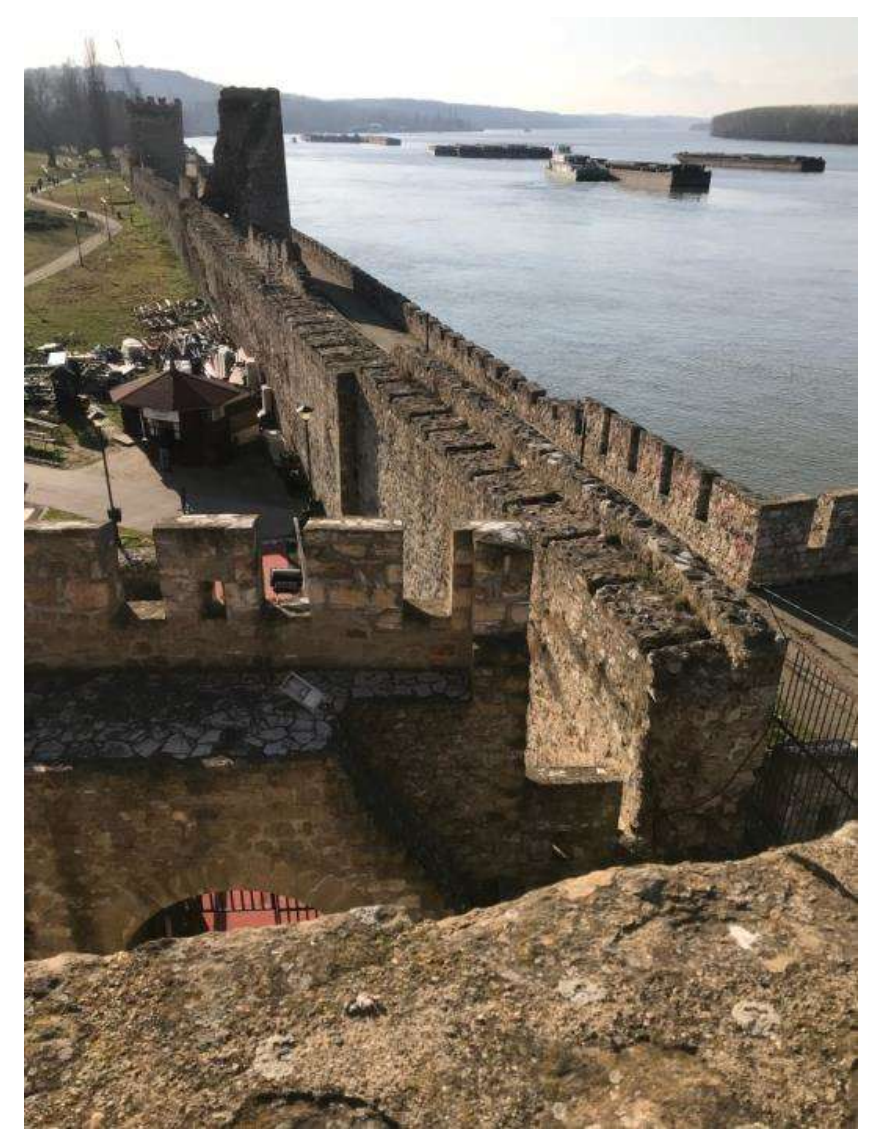

Figure 9. The Smederevo Fortress and the Danube River (author: Uroš Radosavljević).

\subsubsection{Educational Master Project Cultural Tourism in Smederevo}

\section{Initiation of the Project Cultural Tourism in Smederevo}

The educational project was realized as a form of cooperation between the University of Belgrade-Faculty of Architecture and the City of Smederevo as a master thesis research and project with the specific topic Strengthening Cultural Identity in the Danube Area on the Integral Urbanism program during the academic year 2017/18 [61]. The research and the master students' project was done under the umbrella of the DANUrB project through the Danube Transnational EU Program as a financing instrument of the European Territorial Cooperation (ETC), better known as the INTERREG. The DANUrB abbreviation stands for Danube Urban Brand, and the project aims to create a regional network through tourism and education to strengthen the Danube's cultural identity by discovering the unused or hidden cultural and social capital [62]. The project's primary goal is to create a spatial-cultural network along the Danube River as one tourism destination brand, with thematic routes and potentials to increase the number of tourists and prolong their stay in the region. The thing that is important for the educational master project, and for this particular research and Special Issue, is that the DANUrB project enables more participatory forms of planning adapted to local contexts in cooperation with 
communities and regional stakeholders. Such inclusive governance, as expected, will create a network for a wide range of stakeholders and a common platform for sustainable cultural and tourism strategy, which can, in turn, bring social and economic benefits from tourism and cultural industry development.

On the academic side, the specific topic Strengthening Cultural Identity in the Danube Area was researched trough six subtopics, namely: (1) Urban regeneration, (2) A web platform to support the local community-led development of cultural tourism, (3) Sustainable urban and spatial planning as a support for strengthening local cultural identity, (4) Cultural tourism, (5) Integrated projects for the sustainable development of the territory, and (6) Territorial development management instruments [61].

The main question posed in the research conception was what the cultural identity of the City of Smederevo is, how to use it in the field of urban development and regeneration in the promotion of the city, and what aspects of authenticity and uniqueness of local cultural identity can be used in the place brand creation. This specific research question was defined, and the focus was on the topic of culture, since 2018 was declared a year of European cultural heritage. The relationships between culture, cultural heritage, and specific identity patterns have been explored on the one hand, and the use of different planning concepts, approaches, and instruments have been practiced on the other hand in the educational project [61].

\section{Stakeholders' Participation in the Project Cultural Tourism in Smederevo}

The first field visit occurred in February 2018 when the research team from the Faculty of Architecture consisting of six mentors and 25 students visited the most important heritage and tourist sites with the development potential of the City of Smederevo: the industrial heritage- the Old Iron factory; the historic city core with the main square and the church; the Danube River waterfront; and the Smederevo Fortress (Figure 10).

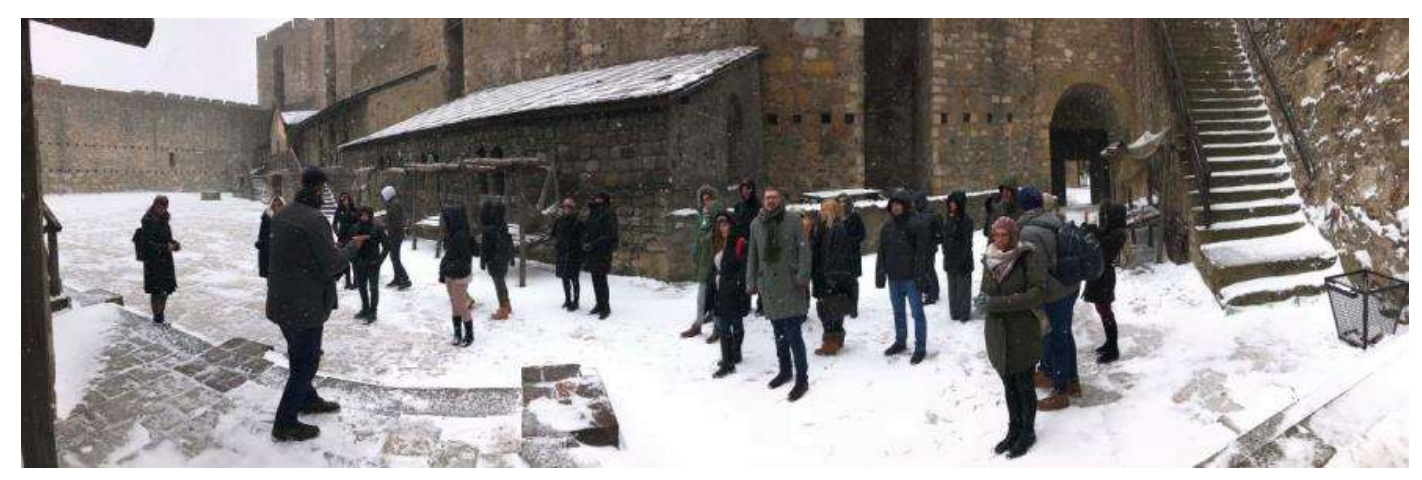

Figure 10. The first field visit to the Smederevo Fortress (Author: Uroš Radosavljević).

The first workshop was held on the same day in February 2018 in the Town Hall of the City of Smederevo [63], where the academic research team presented the goals and structure of the educational project, six subtopics as divergent yet compatible research paths, the expected results, as well as the timeframe. Stakeholders representing the city administration were present, including the mayor of the City of Smederevo, who opened the workshop and the launch of cooperation, as well as the other stakeholders from the Office of the City Urbanist, Department of Local Economic Development, Tourist Organization of the City of Smederevo, the Regional Institute for the Protection of Cultural Monuments in Smederevo, as well as citizens and urban and rural households.

In the period following the first workshop, from February to May 2019, six mentors with their dedicated students commenced the research of their specific guided subtopics described above.

The topic of Cultural tourism is relevant to this article, and the issue of culture, tourism, and inclusive forms of governance. It comprises the research of culture, cultural identity and tourism, which have been researched in the Master studio and will be presented in the remainder of this section [23]. 
The Proposed Themes for Heritage Interpretation

The idea was to explore the intangible aspects of cultural heritage and identity and involve them, either entirely or some of the components, with material and physical tangible heritage solutions into students' urban design projects. This particular idea and conceptual approach expand beyond just relating intangible and tangible cultural heritage, since it has the intention to create favorable integral solutions. Those solutions would enable the sustainable social and economic development of the territory in question-creating social bonds among tourists and community members themselves and with tourists, and creating jobs and employment along with enlarging service economy in such connected, networked way.

To sum up, the idea was to interpret both tangible and intangible elements of cultural heritage both in the City of Smederevo and into the broader territory of the municipality of Smederevo that could be used as assets for the place-branding visions and particular projects. Consequently, students have been guided to explore specific aspects of cultural identity. Those aspects comprised the analyses of the specific way of life, customs, economy, and agriculture, including traditional cuisine, wine, and music. Additionally, the characteristics of the environment and landscape have been researched, as well as listening to diverse local narratives and legends shared by community members.

The proposed themes for heritage interpretation included several interpretive elements present in the area of the city and the municipality of Smederevo, such as the traditional craftsmanship, ways of food preparation, vernacular architecture, steel as a traditional building material, and its use for making jewelry, new urban furniture and for the fortress towers. Under those circumstances, four students started their preliminary guided research.

In such a setting, the specific research topics were assigned to students within this studio in line with their research interests and capabilities. Four different yet interconnected themes of the research have been identified: (1) Sustainable gastro-tourism in rural communities, (2) Old craftsmanship promotion, (3) Activating the Smederevo Fortress to satisfy the needs of modern-day tourists, and (4) Steel as a city-branding element. The comprehensive study is presented in detail in the book chapter Branding Places through Culture and Tourism [23], and we will present here just the small part of that research that is important for this Special Issue.

The methodology in this studio has been conceptualized and practiced since 2008 on the Urban Management course [64] at the Faculty of Architecture in Belgrade, usually with the cultural tourism and sustainable tourism topics in relation to place branding, heritage, and urban management and design concepts (Figure 11).

Students have used the content analysis method in several stages of the research-such as spatial planning and strategic documents-to enable systematization of the critical elements of the analysis and to obtain knowledge of the city's strategic objectives in the field of tourism, spatial planning, rural and agricultural development, and the economy. Equally important was to determine the position of cultural tourism in the structure of the tourist economy of the city and the whole territory of the municipality of Smederevo. However, the research revealed that most of the strategic documents have been based on generalized solutions that neglect specific local resources, community needs and interests, and hence, distinct local community identities. That was the very reason why students have been directed to identify the local stakeholders' needs by exploring the authentic cultural identity, assets, households, food, wine, agricultural products, crafts, music, folklore, and customs. It was an attempt to analyze the possibilities of using these elements of authentic cultural identity and intangible heritage in the integral place-branding strategies and specific urban design projects for the adaptive reuse of cultural tangible heritage.

This approach was further tested and upgraded through collaborative workshops conducted in order to identify the needs of local stakeholders and recognize the key development constraints and opportunities of the territory of Smederevo. In that particular way, students analyzed existing relations between cultural and tourism uses and programs on the one hand, and urban structure and the entire territory and its development potentials on the other. 


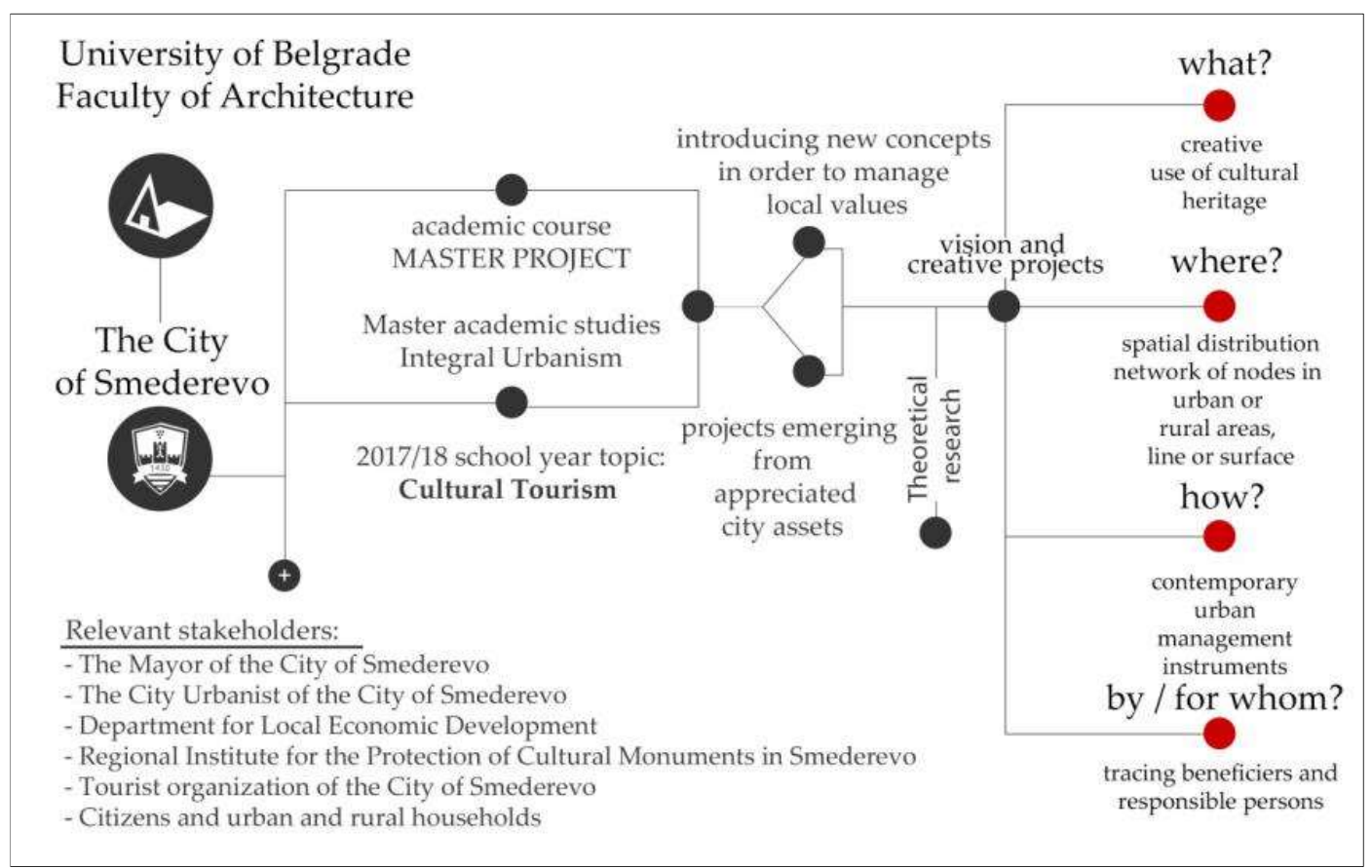

Figure 11. Model of the applied methodology in the educational project in Smederevo [23].

The second workshop was held on 29 May 2018 in Smederevo [65], when the draft research of all six mentoring teams from the Faculty of Architecture and 25 students' master theses and projects were presented and discussed with local stakeholders in the town hall of the city of Smederevo. Stakeholders such as representatives from the city administration, the City Urbanist, the Department of Local Economic Development, the Tourist Organization of Smederevo, and the Regional Institute for the Protection of Cultural Monuments, as well as a number of citizens, were all present and gave useful suggestions and recommendations that have been considered in final projects. In the following part of this section, we will present specific student projects.

\section{Student Projects: Cultural Tourism in Smederevo}

The sustainable gastro-tourism in rural communities project investigated the relation between cultural tourism, cultural identity, and local communities, particularly the way in which these interrelations could enhance the social cohesion and economic revival of villages and strengthen the cultural identity of Smederevo, and thus contribute to the successful place branding of the city, the fortress, and the municipality. The project uses specific traditional ways of food preparation as the intangible heritage element. Accordingly, it serves as a basis for gastro-tourism in rural areas on the one hand and as a branded product in the city of Smederevo and the fortress during various cultural and tourist manifestations on the other (Figure 12).

The possibilities, conditions, and probable risks for gastro-tourism development in rural communities have been identified in this specific project based on theoretical insights, benchmarking analyses, and the inputs conducted from in-depth semi-structured interviews in six local villages. The project consists of creative concepts to utilize the local values of intangible heritage of food preparation for gastro-tourism in two distinctive ways. One way refers to the adaptive reuse of traditional vernacular architecture in the form of tourist accommodation facilities, a cooperative kitchen for tourists preparing the food, and the reconstruction of the market stores in villages for locally grown products. The other way represents newly designed elements such as the construction of bicycle paths for better accessibility among the villages, the city, and the fortress, and the tourist signalization. These two concepts are presented in Figure 13. 


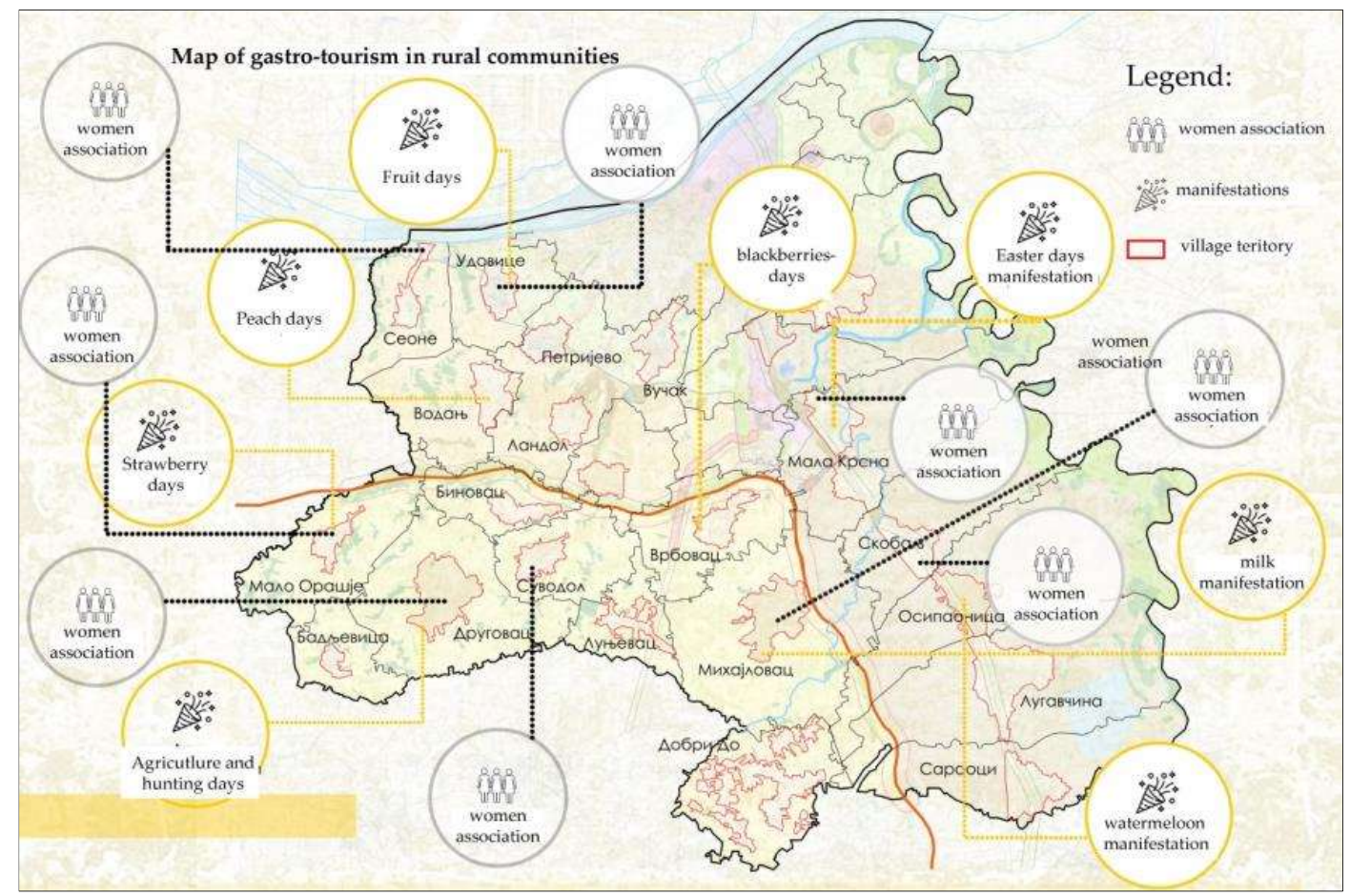

Figure 12. Analysis of the intangible heritage and potentials for gastro-tourism in rural communities in Smederevo (author: student Aleksandra Ilić).

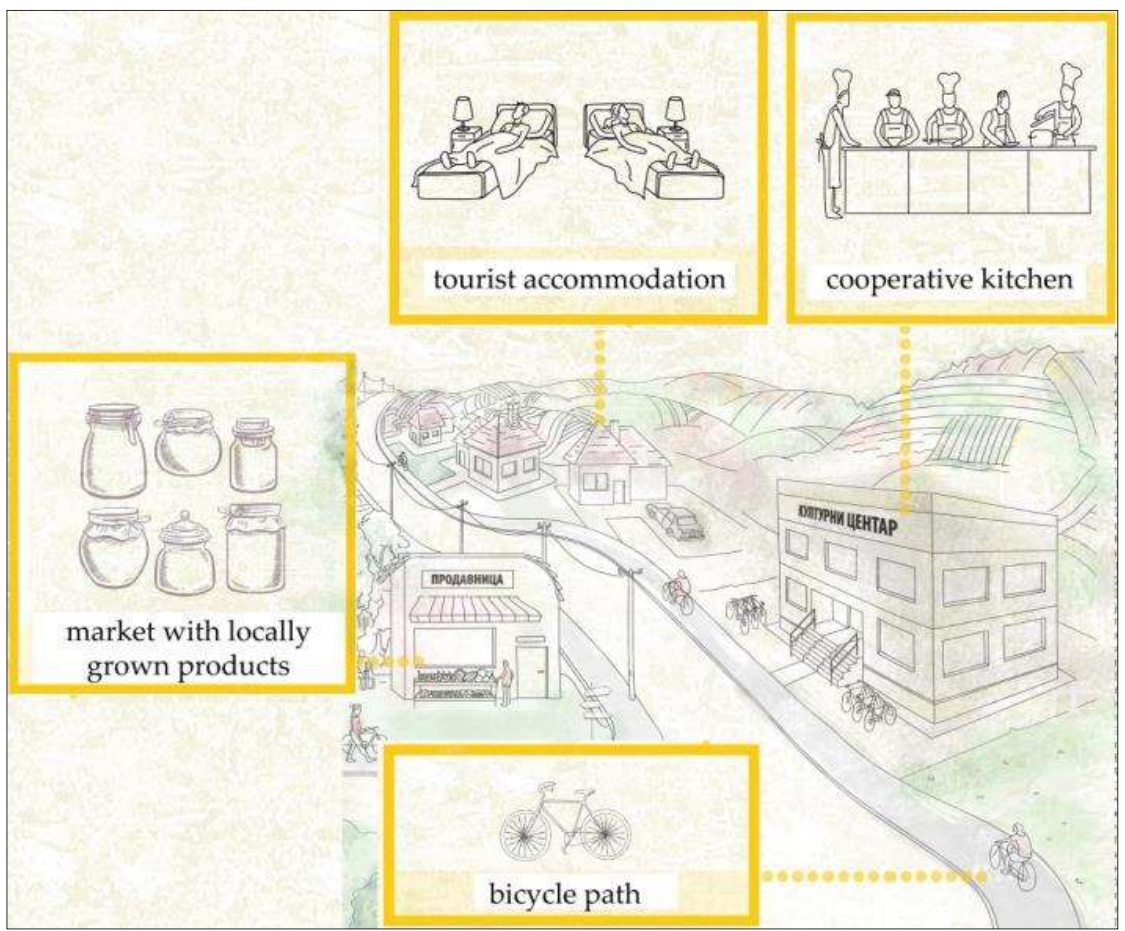

Figure 13. Adaptive reuse of traditional vernacular architecture for tourist accommodation, cooperative kitchen, and the stores for locally grown products (author: student Aleksandra Ilić).

The old craftsmanship promotion project aimed to promote traditional craftsmanship as the intangible heritage and the main potential for cultural tourism, thus contributing to the local economy in a sustainable way. It might have an effect on the revival of traditional and art crafts through contemporary rebranded products that could attract tourists, increase social capital, provide additional income for local households, and promote the city of Smederevo. 
The project contains promotional and organizational actions, such as the inclusion of Smederevo's old crafts into the Danube regional strategies, as well as marketing campaigns during cultural events and promotional steel pavilions for specific craftsmanship products, spatially distributed in the Smederevo Fortress and the city itself (Figure 14).

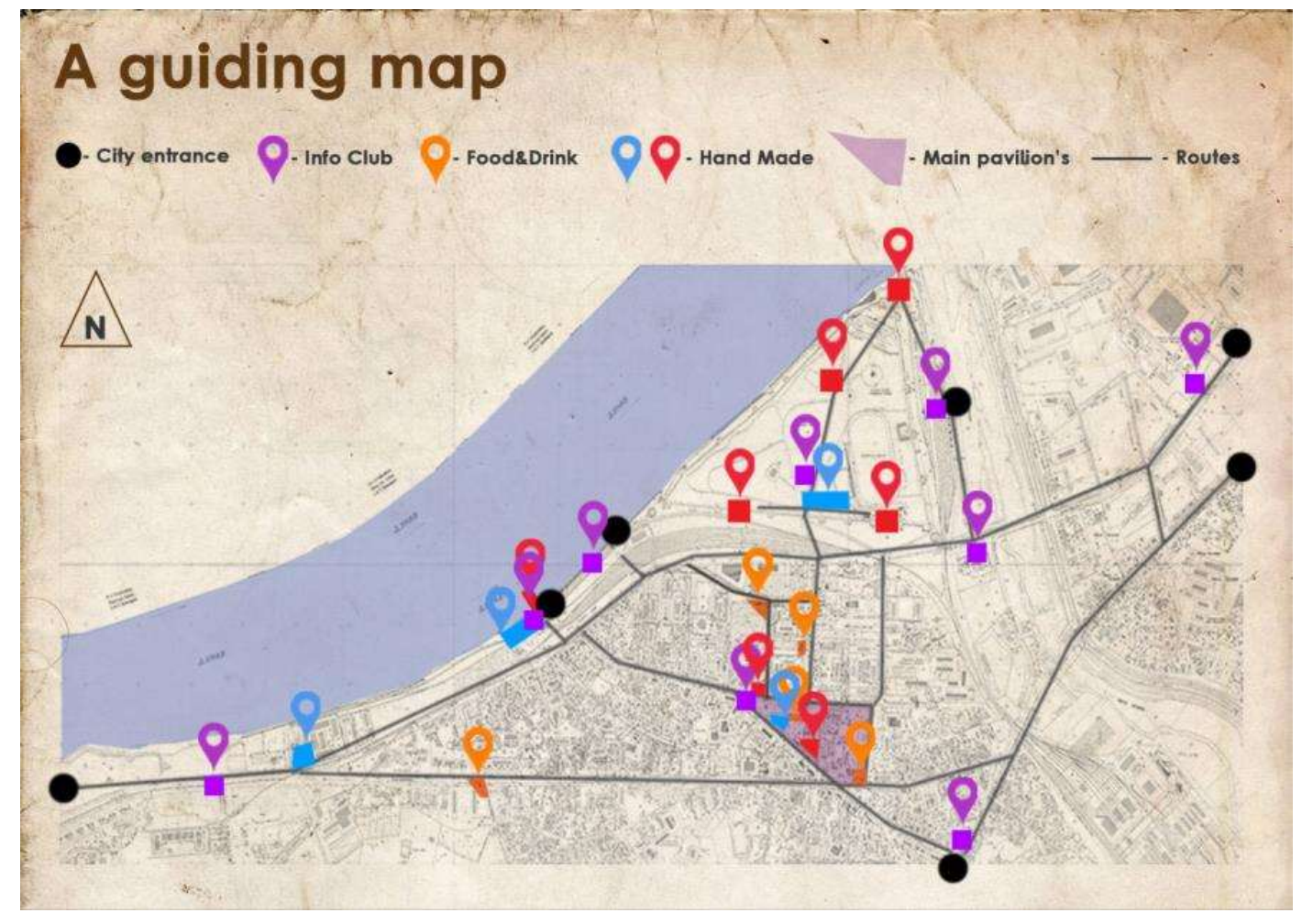

Figure 14. Spatial distribution of pavilions and a guiding map (author: student Aleksandar Lukić).

The project proposes variations of pavilion typology depending on the different needs of the craftsmanship products to be exhibited as the first variable, such as food, vine, art, handcrafts, and tourist information. The other variable refers to the location in the sense of adapting to the surrounding heritage characteristics, architectural style and ambience. Therefore, it differs depending on whether the pavilion is placed in the open public spaces, in the fortress, or somewhere else in the urban structure of Smederevo. Moreover, pavilion typology can be permanent or temporary, as well as free standing, interpolated, or integrated into the existing urban fabric. Additionally, in line with the specific local agricultural and craftsmanship products characteristic of the Smederevo region, different thematic maps and tourist interpretative itineraries (Figure 15) have been created with local tour guides and storytellers, connecting diverse pavilion types, and thus providing an opportunity for a tourist to gain valuable experience of the city and its surroundings.

The activation of the fortress to satisfy the needs of a modern tourist project endeavored to discover new, contemporary ways to make old fortifications more attractive for contemporary tourists, and yet protect the cultural and historical value of the heritage. The forms of adaptive reuse and activation of the fortress were defined with relation to Nešković's previous research [66]. Building on that research, the activities to transform the fortress into an archaeological park with historical ambiance, and the revitalization of some parts of it into museums, galleries, tourist accommodation, and service facilities were further developed in the project.

Open space in the Big Town of the fortress was planned for cultural and art events, including existing festivals, cultural activities, and sports activities, with potential risks for the protection and authenticity of the fortress. For this reason, the project proposes temporary structures and thematic routes for connecting the fortress assets, representing a set of locally unique values (Figure 16). 


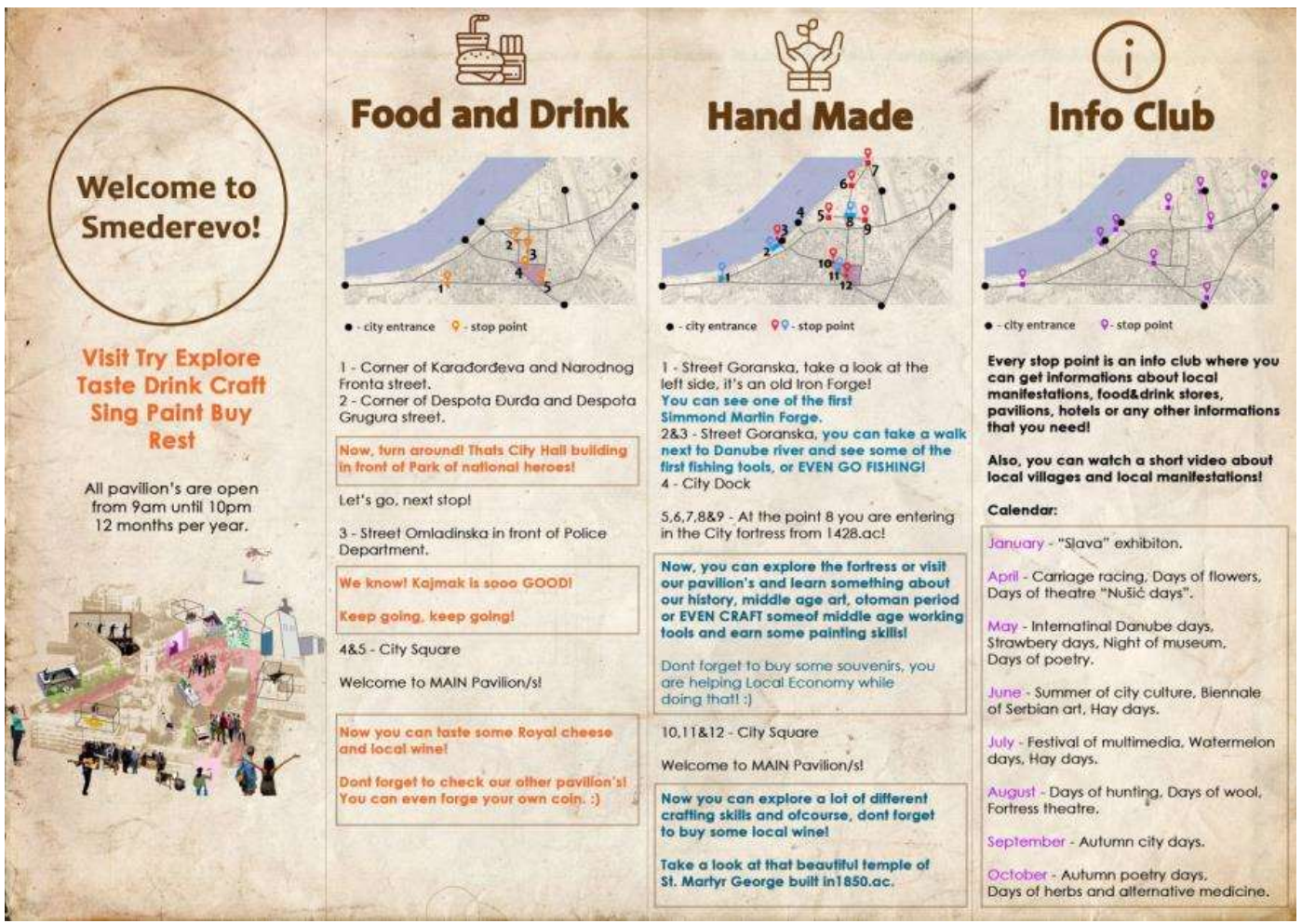

Figure 15. Tourist interpretative itinerary (author: student Aleksandar Lukić).

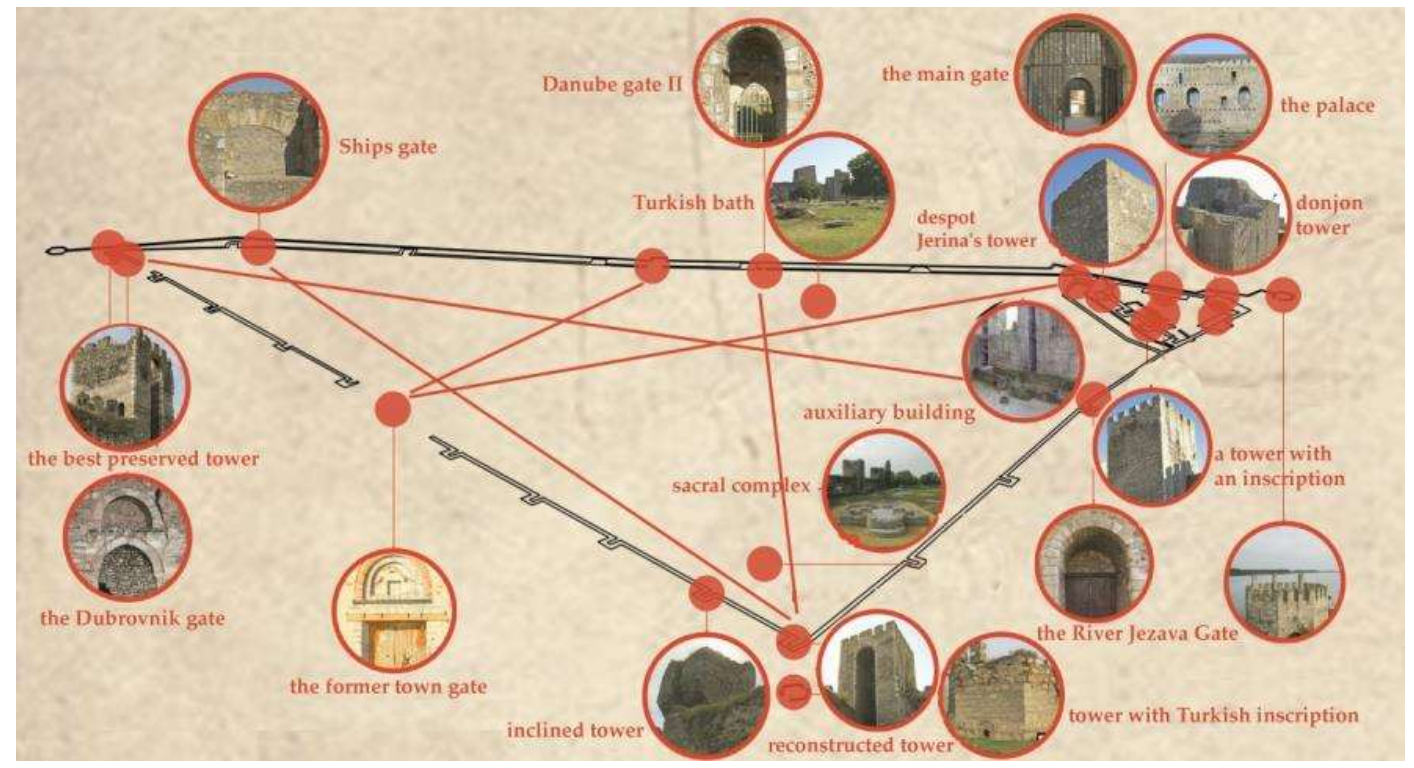

Figure 16. Fortress thematic routes (author: student Sara Kovačević).

The historical route connects towers and gates, since they are neglected at the present moment. The cultural route includes structures for the library, sculpture park, exhibition, open-air theatre, and a stage for concerts. The sports route brings the outdoor gym, playgrounds, chess field, and open-air cinema (Figure 17). 


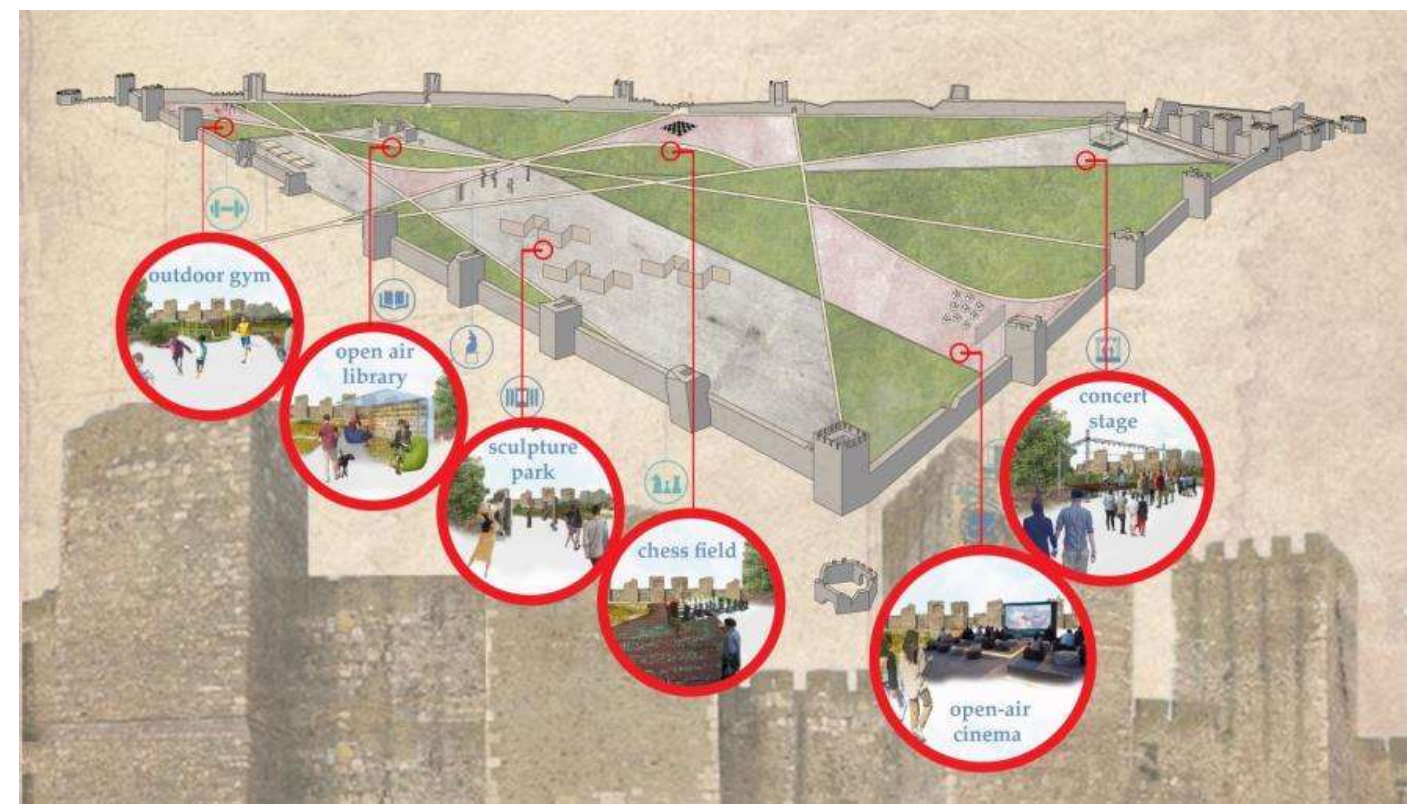

Figure 17. Thematic historical, cultural and sport routes (Author: student Sara Kovačević).

All of these activities require technical protection measures of the specific parts of the fortress, including the adaptation of existing infrastructure, lighting, and safety measures. Other activities for the tourist utilization of the fortress-such as the tourist information center, restaurant, accommodation facilities, and the port on the Danube River-are planned in the vicinity of the fortress, at the mouth of the Jezava River into the Danube, following the regulatory plan of the city of Smederevo.

The steel as a city-branding element project investigated conditions for a specific element of the city identity-such as steel, in this case-to become an attractive place brand for tourists, thus contributing to sustainable development. Steel has been recognized as a cultural and material industrial heritage and one of the hallmarks of the city's identity, due to the long tradition of steel production.

The project envisions a comprehensive branding strategy with specific activities. These activities consist of educational workshops about the innovative use of steel; the inclusion of the old steel factory into the tourist offer with reactivating the production of newly designed products such as traditional tools, jewelry, and decorations; improving the city image by creating new urban furniture made of steel; and design guidelines prescribing the use of steel in new projects and projects undergoing reconstruction within the city. The project proposes that the fortress towers should be reconstructed with steel as a material resembling the city's identity (Figure 18).

Apart from the fortress, the Danube River and the riverfront, as the historical industrial heritage, have been recognized as carriers of the cultural identity. Thus, a newly redesigned promenade with mobile electric-powered trolleys to connect the old steel factory and the fortress along the Danube riverfront was envisioned. Additionally, lighting, urban furniture, canopies of steel, and a sliding track along the promenade were planned, along with steel sculptural exhibitions, thus creating a unique place attractive for tourists. Moreover, the reconstruction of the former silos into lookouts and the redesign of the public space in front of the fortress with the use of water mirrors and steel elements has been designed, as well as a new walkway with steel elements along the fortress wall (Figure 19). 


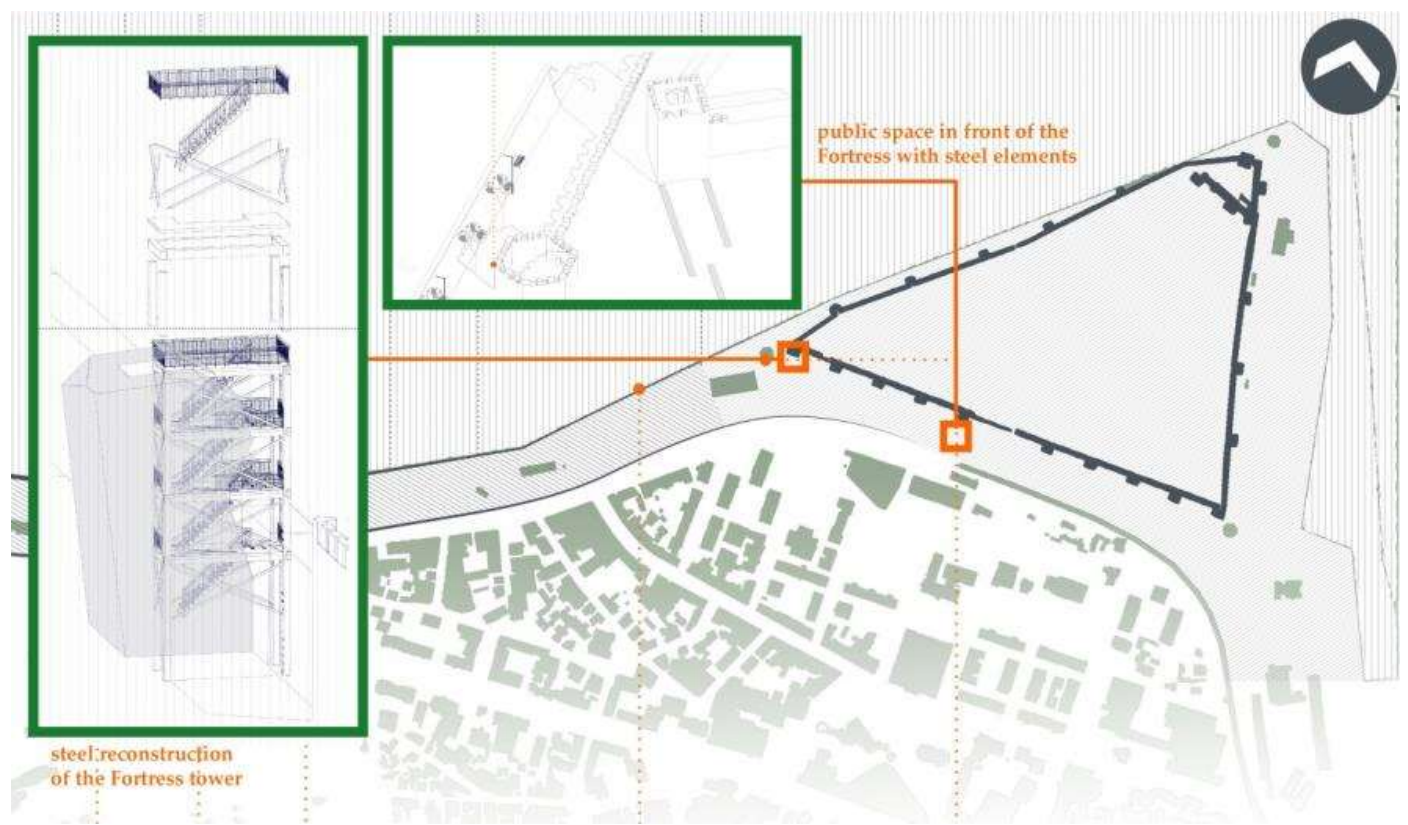

Figure 18. Steel as a brand in detailed specific urban elements—-fortress tower (author: student Uroš Marković).

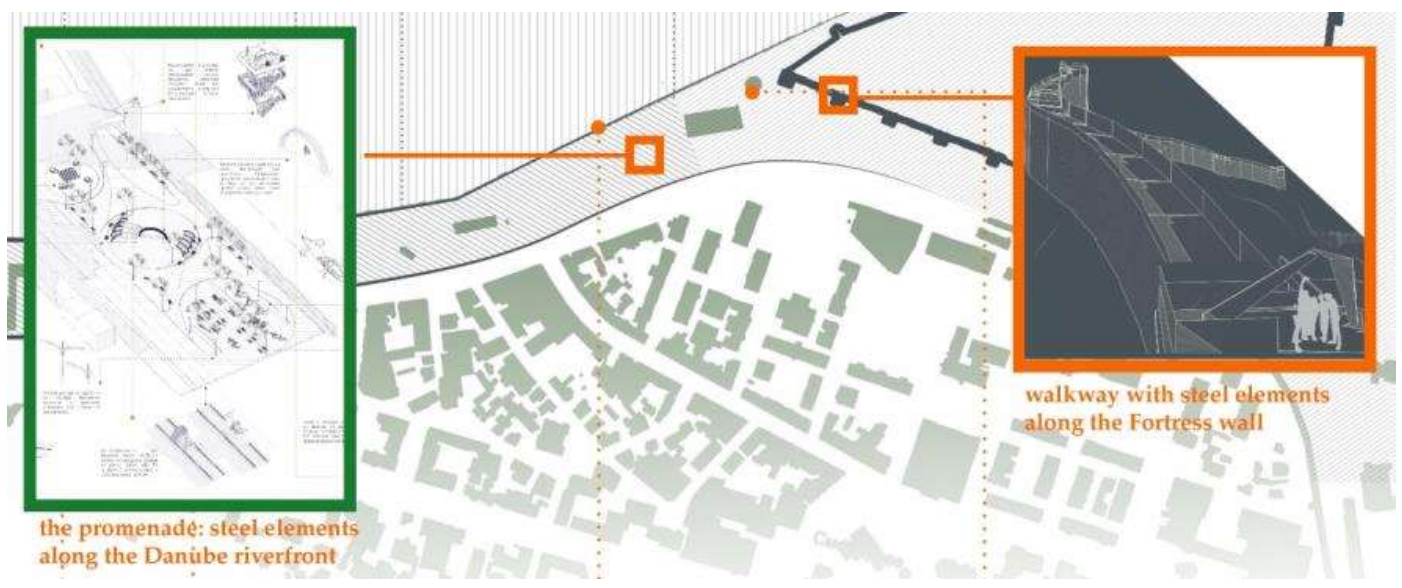

Figure 19. The redesigned Danube riverfront promenade with urban steel furniture (author: student Uroš Marković).

\subsubsection{Results of the Educational Project Smederevo Cultural Tourism}

An essential artifact of the project and cooperation between the city of Smederevo and the faculty was the scientific book Integrative Strategic Planning and Design for the Strengthening of Identity and Cultural Tourism in the Danube Cities_Smederevo [67] published by the Faculty of Architecture. The book consists of respective topics of the six mentors' research methodologies, and the theoretical frameworks for the students' work within the studio and in line with the DANUrB project.

An additional yet significant result of the project's visibility was the master students' project exhibition The Strengthening of Cultural Identity in the Danube Region-Smederevo in the city center of Smederevo in the cultural center held in September 2018. The exhibition raised citizens' attention with inspiring ideas on how the city should use its heritage assets to produce tourist products, facilitate future urban development, and create a recognizable place brand along the Danube River. The students' projects were presented in the exhibition catalog with all 25 final master students' designs from the Integral Urbanism master course. 


\section{Discussion}

The paper presents the potential of the Smederevo and Golubac fortresses' heritage combined with the analyzed intangible cultural heritage to become instruments for the creation of effective place-branding tourism and planning strategies and urban design projects exercised through the educational projects.

The educational projects have highlighted the collaboration, interdisciplinarity, and cooperation between the participants from academia, culture, tourism, the local government, and other branches of industry, and contributed to the introduction of innovative perspectives that offer multifaceted, accurate, and complete solutions. Cooperation between participants and stakeholders is not reduced to a linear communication process through which each participant seeks only to satisfy their interests. On the contrary, the aim is to improve common interests and achieve higher humanistic goals in terms of increasing the awareness of all participants about the problems under consideration. This implies that the potential flow of inclusive tourism takes place in the following way: presentation-consumption-acquirement of knowledge-preservation. What is achieved in this way, through this cycle of communication and collaboration among the participants, is a higher and more valuable, sustainable cycle of maintenance and revitalization of those elements of heritage that are often marginalized, yet its emphasis can attain far-reaching results.

Different dimensions of the sustainable treatment of fortresses and their surroundings in educational projects can be seen through the activation of their tourist potential in a way that enables the development of cultural tourism through the involvement of the local community and the development of social capital. Additionally, it can be observed through the fact that the overall tourist capacity does not jeopardize the values of cultural and historical heritage. Table 1 provides an illustration of the relevant stakeholders' engagement in the process of the projects' conduction and the type of their inclusion in the place-branding process. Furthermore, it offers a review of the types of tangible and intangible heritage used, as well as the themes for the heritage interpretation, environmental aesthetics, and place-branding strategies employed during the process.

The whole process was primarily done in a participatory manner with the inclusion of stakeholders from different levels, depending on the specific topic considered and at various stages of the development process of the educational projects. In this way, the vertical and horizontal integration of interests through the initiation and development of possible partnerships for the realization of specific measures and small projects have been achieved. Participation was organized in several iterative cycles that reflected various levels of stakeholder participation through interactive workshops, round tables, discussions, and intersectoral thematic meetings. The interactivity of the participation process enabled the constant checking and redefining of identified problems, goals, and measures.

However, the need for the heritage protection on the one hand, and the need for the economic development of the same valuable assets, on the other hand, requires an integrated approach. Following the principles of sustainability, a holistic approach implies the simultaneous preservation of non-renewable resources, such as cultural heritage (the fortress in this case), and the enablement of its development with positive externalities to other sectors of sustainability, such as the economy, social cohesion, and ecology. Nevertheless, the entrepreneurial approach to regeneration, in general, has two potential challenges for the local context, heritage, and cultural identity. One is how to control globalization impact on a local level without neglecting local culture, but still securing competitive advantage. The second challenge is how to appropriately present the uniqueness and specificity of local cultural assets and still make them understandable to the contemporary world. Bearing those two challenges in mind, this approach has been reflected throughout the students' proposals in educational projects in both the Smederevo and Golubac case studies and within the plan conduction in the Golubac case study.

The challenges mentioned above could be best tested through the confirmed examples of touristic and place-branding use of medieval cultural heritage, especially castles and fortresses, across Europe. Therefore, we provide here a brief comparison of the place-branding experience of fortress-linked 
heritage in Serbia and Italy to make it relevant for similar research and for situations of cultural heritage used for place branding and cultural tourism for theoreticians, practitioners, and community members going beyond merely educational projects.

Table 1. Comparative analysis of cases.

\begin{tabular}{|c|c|c|}
\hline Elements of Analyses & Golubac Fortress & Smederevo Fortress \\
\hline Relevant stakeholders & $\begin{array}{l}\text { Public: national/regional/local } \\
\text { level, Tourist Organization of } \\
\text { Serbia and Golubac; } \\
\text { Private: tourist businesses, local } \\
\text { catering association }\end{array}$ & $\begin{array}{c}\text { Public: regional/local level, Tourist } \\
\text { Organization of Smederevo; } \\
\text { Civil: citizens, urban and rural } \\
\text { households }\end{array}$ \\
\hline $\begin{array}{l}\text { Type of stakeholders' } \\
\text { inclusion in the } \\
\text { place-branding process }\end{array}$ & $\begin{array}{l}\text { Workshops/field visits/individual } \\
\text { encounters and } \\
\text { meetings/interviews }\end{array}$ & $\begin{array}{c}\text { Workshops/design charrettes/field } \\
\text { visits/joint meetings/semi-structured } \\
\text { interviews }\end{array}$ \\
\hline $\begin{array}{c}\text { Type of tangible heritage } \\
\text { used }\end{array}$ & $\begin{array}{l}\text { Fortress walls, rooms, towers, } \\
\text { traditional building materials }\end{array}$ & $\begin{array}{l}\text { Fortress walls, rooms, towers, } \\
\text { traditional building materials }\end{array}$ \\
\hline $\begin{array}{c}\text { Type of intangible heritage } \\
\text { used }\end{array}$ & $\begin{array}{l}\text { Legends, historical facts, } \\
\text { traditional building techniques }\end{array}$ & $\begin{array}{c}\text { Food and wine, legends, stories, } \\
\text { historical facts, crafts, steel, traditional } \\
\text { construction techniques }\end{array}$ \\
\hline $\begin{array}{l}\text { Themes for heritage } \\
\text { interpretation }\end{array}$ & $\begin{array}{l}\text { Tourist attractions as a mix of } \\
\text { natural and built } \\
\text { environment/Land and water } \\
\text { accessibility to the fortress/Tourist } \\
\text { accommodation and services in } \\
\text { and around the fortress/Adaptive } \\
\text { reuse and activation of authentic } \\
\text { walls, towers, and rooms of the } \\
\text { fortress/Information center and } \\
\text { promotional } \\
\text { activities/Ethno-tourism for nature } \\
\text { and healthy living }\end{array}$ & $\begin{array}{l}\text { Traditional craftsmanship/Traditional } \\
\text { ways of food preparation for modern } \\
\text { cultural tourism/Traditional } \\
\text { vernacular architecture for tourist } \\
\text { accommodation/Adaptive reuse of the } \\
\text { fortress for the contemporary } \\
\text { tourists/Steel as a traditional building } \\
\text { material, and its use for the } \\
\text { reconstruction of the fortress towers, } \\
\text { jewelry, and new urban furniture }\end{array}$ \\
\hline Environmental aesthetics & $\begin{array}{c}\text { Natural environment-The } \\
\text { Danube, the Djerdap National } \\
\text { Park } \\
\text { Biodiversity and balanced } \\
\text { ecosystem } \\
\text { Extraordinary aesthetic experience: } \\
\text { interrelation of nature and cultural } \\
\text { heritage } \\
\text { Cultural heritage tourism through } \\
\text { environmental health therapy of } \\
\text { specific aesthetic and emotional } \\
\text { experiences }\end{array}$ & $\begin{array}{l}\text { Natural environment-The Danube, } \\
\text { surrounding urban environment } \\
\text { Cultural and social values in } \\
\text { interaction with aesthetic values } \\
\text { Environmental aesthetics of fortress } \\
\text { architecture and its benefits through } \\
\text { "living" intangible character and } \\
\text { atmosphere of the place } \\
\text { (manifestations, history, storytelling } \\
\text { traditions)/forming complex aesthetic } \\
\text { experiences of the environment }\end{array}$ \\
\hline $\begin{array}{l}\text { Place-branding strategies } \\
\text { employed }\end{array}$ & $\begin{array}{l}\text { Recognition of the identity of the } \\
\text { local population/Personality } \\
\text { association with historical } \\
\text { figures/Visual qualities of } \\
\text { buildings and urban design of the } \\
\text { fortress and surrounding tourist } \\
\text { buildings and interpretative } \\
\text { signposts/Promotional activities } \\
\text { on the web and in the tourist } \\
\text { information center }\end{array}$ & $\begin{array}{l}\text { Recognition of the identity of the local } \\
\text { population/Personality } \\
\text { association/Visual qualities of } \\
\text { buildings and urban } \\
\text { design/Promotional activities in the } \\
\text { form of tourist interpretative } \\
\text { itineraries and promotional steel } \\
\text { pavilions/Event hallmarking for } \\
\text { cultural and art performances }\end{array}$ \\
\hline
\end{tabular}

A successful example of the place-branding experience of the interpretation and use of tangible and intangible heritage can be seen in the case of traditional rural buildings and Donnafugata Castle, 
located $20 \mathrm{~km}$ from the Ragusa city in southeastern Sicily in Italy. The castle itself has a significant historical and architectural reputation and hosts various social and cultural events and exhibitions that are important for tourists. The study researched and presented by Leanza, Porto, Sapienza, and Cascone [68] shows an effective planning strategy for a tourist itinerary in rural areas for promoting cultural rural heritage and diversifying the tourism offer. The tourist itinerary-covering the area of about $51 \mathrm{~km}^{2}$-combined the traditional rural buildings and enogastronomy with an already popular tourist attraction in Donnafugata Castle.

An essential aspect of the effective place-branding process was the implementation of the Interpretation Center in the Donnafugata Castle. In the center, tourists can acquire knowledge on the castle's building materials and techniques, which were used as interpretive elements in the research study and the tourist itinerary [68]. It was expected that if knowledge of the building materials and techniques-such as limestone, asphaltic stone, and wood-was disseminated among visitors, it might inspire tourists to learn more about the local community, their culture, and the building forms that are typical for the territory in question [68]. Additionally, the information about the surrounding area and the map of the heritage interpretation-based itinerary with suggestions for the stopping points and the street network is available at the Interpretation Center.

Besides the Interpretation Center in the Donnafugata Castle, there are several other aspects used for the effective place-branding process and implementation of the heritage interpretation-based itinerary. The first is the bilingual didactic panel at the entrance of the castle, containing information about architectural details and building techniques, as well as the itinerary of the castle and traditional rural buildings in the area. The second is the didactic panel at the tourist route stopping points, containing rural architecture topics and information about different locations and themes, such as the enogastronomy - with wineries and museums exhibiting tools of the traditionally produced wine and oil; farms on which tourists can experience the production of local cheese, wine, and oil; the archeological areas; and the Baroque architecture of churches and palaces in nearby cities included in the UNESCO World Heritage list. The third is a mini-guide for the self-guided tours with the information about what could be experienced at specific stopping points. The fourth is the implementation of the geographical information system, which is used to store information about the tourist accommodation in the area near the castle, as well as traditional building materials and techniques, the road network, and traffic. The last aspect is the information and the map of connections within the area of the heritage interpretation-based itinerary [68].

By comparing the place-branding experience of fortress-linked heritage in Serbia and Italy, we can observe that most of the specific elements of the interpretation and use of tangible and intangible heritage in the Italian case support and justify the approach in the Serbian cases of the Golubac and Smederevo fortresses. This stands for the proposed themes for heritage interpretation, as well as the tangible and intangible elements of cultural heritage used in the interpretation of places within educational projects. On the other hand, intangible aspects of the analyzed heritage themes' interpretation are present in Serbia only in educational projects, while in the Italian case, they form a unique amalgam with tangible heritage.

Moreover, the possible future strategy and research for the development of tangible and intangible heritage could include different methods. Besides the analysis of European examples of successful instances of place-branding experience and the interpretation and use of tangible and intangible heritage, we can proceed with creating cultural routes along the Danube River. Routes are different historical ways that connect cultures, historical heritage, and events, highlighting the interdependence and symbiosis of intangible and tangible cultural heritage [69]. Through cultural routes, we understand relationships, and share knowledge, values, ideas, and other multifaceted influences between people. The key point of cultural routes relates to communication. There may be many individual heritage elements when we consider cultural routes that are both intangible and tangible, such as fortifications, urban centers, archeological sites, architectural sites, places of significant historical events, cultural and natural landscapes, venues for performances, festivals and different events, etc. 
By creating cultural routes along the Danube, which is already a natural route, different elements of cultural heritage could be incorporated with its tangible and intangible features, thus contributing to a more comprehensive approach of creative and sustainable cultural heritage tourism development in Serbia. In order to realize and promote new cultural routes, the efficient and joint cooperation of cultural institutions, municipal agencies, and regional agencies with participants from the tourism sector are required. The creation of these cultural routes as a primary condition requires an adequate relation between tangible and intangible cultural heritage, linking historical monuments, sites, and places with other intangible cultural resources such as the customs and habits of the people, traditions, rituals, religions, handicrafts, art crafts, music, dance, literature, social narratives, festivals, traditional markets, communities, beliefs, lifestyle, social identity, etc.

Creating cultural routes on the Danube along the Smederevo-Golubac path in the Lower Danube region can contribute to the creation of authentic experiences that enhance tourism in Serbia. Here are some potential examples of cultural routes in Serbia along the Danube: the cultural route Danube-Border and the Crossroads of Cultures, Paths of Medieval Serbia-surrounding the Danube and beyond, Ancient Roman Paths - covering the Danube and beyond, Paths of Buried Treasure of the Damned Jerina, Dragon Paths through Medieval Serbia, Sieges of the Golubac Fortress, and Construction of the Smederevo Fortress. The inclusion of the Smederevo and Golubac fortresses in the unique design of a thematic route along the Danube has the potential to attract foreign and domestic tourists and contribute to the development of place-branding strategies.

\section{Conclusions}

By introducing intangible cultural heritage into the focus of cultural tourism, the scope of stakeholders in tourism has expanded considerably. The focus of this approach was not only on the particular historical monument of the fortresses and the surrounding conservation area, but also on the much broader environment and stakeholders' active involvement. This means that the ancient monument and its surroundings were interlinked with the social, economic, and spatial net, giving specific impetus to the urban development. In the formation of a place-branding strategy for touristic reuse of the Golubac and Smederevo fortresses, the following stakeholders were involved in the collaboration processes: the local community, individuals and indigenous people, the Ministry of Culture and Media of the Republic of Serbia, the Ministry of Trade, Tourism, and Telecommunications, the National Committee for the Safeguarding of Intangible Cultural Heritage of the Republic of Serbia, the Ethnographic Museum in Belgrade, the Commission for the Inscription of Intangible Cultural Heritage in the National Register, regional coordinators responsible for central and eastern Serbia, touristic agencies, academic experts, scholars, museums, and other cultural institutions.

The presented case studies in this paper have demonstrated multiple benefits based on a multifaceted approach in solving everyday problems by providing synergy in outcomes that have been able to satisfy even the often-conflicted stakeholders. The ultimate product of this participatory collaboration, while respecting the legal framework and policies, emphasized the necessity of harmonizing the goals of cultural heritage safeguarding while satisfying tourism stakeholders, whose primary goal is to achieve as much profit as possible. The inclusive approach in practice has supported theoretical, social, and humanistic goals and served as a starting point for achieving the general goal of sustainability. Consequently, in order to achieve sustainable tourism development, profit must be limited and reduced to an adequate measure that does not violate the principles of cultural heritage protection.

In terms of governance and planning, the inclusion of different relevant individual local and national stakeholders and organizations, ranging from the various local government and public enterprises and agencies, as well as community members, including residents, in the whole educational and planning process had multiple objectives. In the first place, it was essential to gather a collection of official data firsthand. Then, it was necessary to gain understanding about their values, interests, and needs, and listen to their narratives to reveal specific tacit knowledge that they possess individually 
on the urban development issues in general and that relates to the culture, tourism, cultural identity and heritage in particular. Furthermore, it was equally important to gain the necessary confidence in personal contact with stakeholders and create strong bonds, and a feeling of mutual understanding and trust for future research steps.

The actual inclusion of stakeholders was done in accordance with the conditions described above, using numerous methods and levels of participation. Various participatory levels included informing, consulting, and occasionally even involving stakeholders who provided suggestions and critical remarks concerning specific students' projects and expert studies. Several participatory methods have been used, such as open-ended questionnaires, semi-structured interviews, several individual meetings with residents and rural households in the wider territory of the Golubac and Smederevo municipality, workshops, and debates with city representatives, all in order to create a platform for establishing a dialogue among stakeholders and provide relevant feedback on the research and specific projects.

Nonetheless, as shown in the paper, while a great number of stakeholders with local knowledge and sense of the spirit of the place have been involved in the planning process, intangible aspects of the analyzed heritage cases are present in educational projects, and only partially present if it comes to the actual implementation and the physical reconstruction, as is the case with the Golubac Fortress. This clearly demonstrates that the focus on tangible aspects and the spatial interventions of place branding of cultural heritage is still dominant in practice in Serbia, despite the acknowledgment of economic and social aspects and the benefits of sustainability in the planning phase in educational projects.

Equally importantly, all of the proposed solutions in both analyzed cases to a greater or lesser extent indeed function as a kind of professional incentive in the attempt to link tangible and intangible heritage use for place branding and cultural tourism. The incentive is for local communities, stakeholders, experts from various fields, and public authority officials-and potentially, if realized, for future tourists. In this particular way, both the tangible and intangible heritage combined in educational projects have been interpreted and presented as a whole tourist and branded package rather than only as an individual element.

The overall research presented in this paper can be used as an informational, practical, and operational basis for further research of the integration of cultural heritage and tourism into practice. The study of the cultural heritage and place branding in educational projects ensures a better visibility of intangible and material cultural heritage. It also raises awareness of their mutual importance and the need of establishing a collaborative dialogue with all tourism stakeholders practicing inclusive forms of governance, while respecting the principles of cultural diversity and sustainability. We sincerely believe that the paper can be relevant for both theoreticians and practitioners bearing in mind the effects and possibilities that careful spatial and program interventions on cultural heritage in small and medium-sized cities can have on the community and sustainable development of its territory.

Author Contributions: Conceptualization, U.R. and I.K.Ć.; Funding acquisition, U.R.; Investigation, U.R. and I.K.Ć.; Methodology, U.R. and I.K.Ć.; Visualization, U.R. and I.K.Ć.; Writing-original draft, U.R. and I.K.Ć.; Writing-review and editing, U.R. and I.K.Ć.

Funding: This research was funded by the Ministry of Education, Science and Technological Development of the Republic of Serbia, under the Grant number TR 36035 “Spatial, Environmental, Energy and Social Aspects of Development of Settlements and Climate Change".

Conflicts of Interest: The authors declare no conflict of interest.

\section{References}

1. European Parliament. Towards an Integrated Approach to Cultural Heritage for Europe. In Proceedings of the European Union Committee of the Regions 111th Plenary Session, Brussels, Belgium, 16-17 April 2015.

2. UNESCO. Convention for the Safeguarding of the Intangible Cultural Heritage; UNESCO: Paris, France, 2003. 
3. Conclusions of the Athens Conference. In Proceedings of the First International Congress of Architects and Technicians of Historic Monuments, Athens, Greece, 1931. Available online: https://www.icomos.org/en/charters-and-texts/179-articles-en-\%20francais/ressources/charters-andstandards/167-the-athens-charter-for-the-\%20restoration-of-historic-monuments (accessed on 8 February 2019).

4. Group of Conservation Professionals. International Charter for the Conservation and Restoration of Monuments and Sites (The Venice Charter 1964). In Proceedings of the Second International Congress of Architects and Technicians of Historic Monuments, Venice, Italy, 25-31 May 1964.

5. UNESCO. Convention Concerning the Protection of the World Cultural and Natural Heritage; UNESCO: Paris, France, 1972.

6. UNESCO. Recommendation on the Safeguarding of Traditional Culture and Folklore; UNESCO: Paris, France, 1989.

7. Government of the Republic of Serbia, Ministry of Trade, Tourism and Telecommunications. Tourism Development Strategy of the Republic of Serbia for the Period 2016-2025. In Official Gazette of the Republic of Serbia; no. 98/2016; Government of the Republic of Serbia, Ministry of Trade, Tourism and Telecommunications: Belgrade, Serbia, 8 December 2016.

8. UNWTO. Report of Secretary-General, A/22/10 (I)(a) rev. 1; UNWTO General Assembly: Madrid, Spain, 2017.

9. Richards, G. Cultural Tourism: A Review of Recent Research and Trends. J. Hosp. Tour. Manag. 2018, 36, 12-21. [CrossRef]

10. Van Assche, K.; Beunen, R.; Lo, M.C. Place as layered and segmentary commodity: Place branding, smart growth and the creation of product and value. Int. Plan. Stud. 2015, 21, 164-175. [CrossRef]

11. Harvey, D. From managerialism to entrepreneurialism: The transformation in urban governance in late capitalism. Geogr. Annal. Series B 1989, 71, 3-17. [CrossRef]

12. Jessop, B. The enterprise of narrative and the narrative of enterprise: Place marketing and the entrepreneurial city. In The Entrepreneurial City; Hall, T., Hubbard, P., Eds.; Wiley: Chichester, UK, 1998; pp. 77-99.

13. Boisen, M.; Terlouw, K.; Groote, P.; Couwenberg, O. Reframing place promotion, place marketing, and place branding-Moving beyond conceptual confusion. Cities 2018, 80, 4-11. [CrossRef]

14. Kapferer, J.N. Strategic Brand Management: Creating and Sustaining Brand Equity Long Term, 4th ed.; Kogan Page: London, UK, 2008.

15. Ashworth, G.J. The Instruments of Place Branding: How is it Done? Eur. Spat. Res. Policy 2009, 16, 9-22. [CrossRef]

16. Govers, R. From place marketing to place branding and back. Place Brand. Public Dipl. 2011, 7, $227-231$. [CrossRef]

17. Kavaratzis, M.; Hatch, M.J. The dynamics of place brands: An identity-based approach to place branding theory. Mark. Theory 2013, 13, 69-86. [CrossRef]

18. Cassel, S.H.; Pashkevich, A. World Heritage and Tourism Innovation: Institutional Frameworks and Local adaptation. Eur. Plan. Stud. 2014, 22, 1625-1640. [CrossRef]

19. Forester, J. Planning in the Face of Power; University of California Press: Berkeley, CA, USA, 1989.

20. Healey, P. Planning Through Debate: The Communicative Turn in Planning Theory. In The Argumentative Turn in Policy Analysis and Planning; Fischer, F., Forester, J., Eds.; Duke University Press: London, UK, 1993; pp. 233-253.

21. Innes, J. Planning theory's emerging paradigm: Communicative action and interactive practice. J. Plan. Educ. Res. 1995, 14, 183-189. [CrossRef]

22. Healey, P. Collaborative Planning: Shaping Places in Fragmented Societies; Macmillan: London, UK, 1997.

23. Radosavljević, U.; Đorđević, A. Branding Places through Culture and Tourism. In Integrative Strategic Planning and Design for the Strengthening of Identity and Cultural Tourism in the Danube Cities-Smederevo; Djukić, A., Kadar, B., Eds.; University of Belgrade, Faculty of Architecture: Belgrade, Serbia, 2019; pp. 70-85.

24. Mako, V. Estetika-Arhitektura. In Sedam Tematskih Rasprava; University of Belgrade, Faculty of Architecture: Belgrade, Serbia; Orion Art: Belgrade, Serbia, 2005.

25. Kuletin, I.Ć. From Big Mac and Ikea Society to The Environmental Aesthetics, Smart Cities and Storytelling Architecture. In Proceedings of the 21th International Congress of Aesthetics-Possible Worlds of Contemporary Aesthetics: Aesthetics Between History, Geography and Media, Belgrade, Serbia, 22-26 June 2019. 
26. Carlson, A. Environmental Aesthetics. In The Stanford Encyclopedia of Philosophy; Zalta, E.N., Ed.; Metaphysics Research Lab, Stanford University: Stanford, CA, USA, 2016.

27. Kepczynska-Walczak, A.; Marek Walczak, B. Built heritage perception through representation of its atmosphere. Ambiances 2015, 1. [CrossRef]

28. Carlson, A. Aesthetic Appreciation of the Natural Environment. In Nature, Aesthetics, and Environmentalism: From Beauty to Duty; Lintott, A.C.S., Ed.; Columbia University Press: New York, NY, USA, 2008; pp. 119-132.

29. Berleant, A. Aesthetics and Environment: Variations on a Theme; Ashgate Publishing: Farnham, UK, 2005.

30. Cooper, N.; Brady, E.; Steen, H.; Bryce, R. Aesthetic and Spiritual Values of Ecosystems: Recognising the Ontological and Axiological Plurality of Cultural Ecosystem "services". Ecosyst. Serv. 2016, 21, 218-229. [CrossRef]

31. Harrison, R. Beyond "Natural" and "Cultural" Heritage: Toward an Ontological Politics of Heritage in the Age of Anthropocene. Herit. Soc. 2015, 8, 24-42. [CrossRef]

32. Wang, H.F.; Chiou, S.C. Study on the Sustainable Development of Human Settlement Space Environment in Traditional Villages. Sustainability 2019, 11, 4186. [CrossRef]

33. Larsen, P.B.; Wijesuriya, G. Nature-Culture Interlinkages in World Heritage: Bridging the Gap. World Herit. Rev. 2015, 75, 4-15.

34. Berleant, A. The Aesthetics of Environment; Temple University Press: Philadelphia, PA, USA, 1992.

35. Böhme, G. Atmospheric Architectures: The Aesthetics of Felt Spaces; Bloomsbury Academic: London, UK, 2017.

36. European Commission. Commission regulation EU No 651/2014, Recital 72. Off. J. Eur. Union 2014, 1-87. Available online: https:/eur-lex.europa.eu/legal-content/EN/TXT/PDF/?uri=CELEX:32014R0651\&from=EN (accessed on 23 September 2019).

37. Cruz, F.G.S.; Torres-Matovelle, P.; Molina-Molina, G.; Gálvez, J.C.P. Tourist Clusters in a Developing Country in South America: The Case of Manabì Province, Ecuador. Sustainability 2019, 11, 4329. [CrossRef]

38. Cattaneo, T.; Giorgi, E.; Ni, M. Landscape, Architecture and Environmental Regeneration: A Research by Design Approach for Inclusive Tourism in a Rural Village in China. Sustainability 2018, 11, 128. [CrossRef]

39. Jelinčić, D.A. Managing Cultural Tourism: A Sustainability Approach: Creating and Managing Experiences in Cultural Tourism; World Scientific Publishing: Singapore, 2019; Volume 1.

40. Duxbury, N.; Bakas, F.E.; Carvalho, C.P.D. Why is Research-Practice Collaboration so Challenging to Achieve? A Creative tourism Experiment. Tour. Geogr. 2019, 19, 1-27. [CrossRef]

41. Ignjatović, A. Jugoslovenstvo u Arhitekturi 1904-1941; Građevinska Knjiga: Belgrade, Serbia, 2007.

42. Harrison, R.; Rose, D. Intangible heritage. In Understanding Heritage and Memory; Benton, T., Ed.; Manchester University Press; Open University: Manchester, UK, 2010; pp. 238-276.

43. Farthing, S. Research Design in Urban Planning: A Student's Guide; SAGE Publications: Los Angeles, CA, USA, 2016.

44. Flyvbjerg, B. Five Misunderstandings About Case-Study Research. Qual. Inq. 2006, 12, 219-245. [CrossRef]

45. Yin, R.K. Case Study Research: Design and Methods, 2nd ed.; Sage: Thousand Oaks, CA, USA, 2009.

46. Kurin, R. Safeguarding Intangible Cultural Heritage: Key Factors in Implementing the 2003 Convention. Int. J. Intang. Herit. 2007, 2, 9-20.

47. Bajić Brković, M. Ka održivom razvoju gradova u Srbiji. In Kreativne Strategije za Održivi Razvoj Gradova u Srbiji; Bajić Brković, M., Ed.; University of Belgrade, Faculty of Architecture: Belgrade, Serbia, 2010; pp. 1-50.

48. Government of the Republic of Serbia. Master Plan Turističke Destinacije Donje Podunavlje; Ekonomski Fakultet, Naučno-Istraživački Centar: Belgrade, Serbia, 2007.

49. Government of the Republic of Serbia. Strategija Razvoja Turizma Republike Srbije. In Official Gazette of the Republic of Serbia; No. 91/2006; Government of the Republic of Serbia: Belgrade, serbia, 20 October 2006.

50. UNESCO. Djerdap National Park, UNESCO World Heritage Tentative List; UNESCO: Paris, France, 2002.

51. UNESCO. Frontiers of the Roman Empire, UNESCO World Heritage Tentative List; UNESCO: Paris, France, 2015.

52. Medić, S.; Rajtenbah, D.; Pavlović, N.; Mudrinski, N. (Eds.) Turistički Vodič Kroz Vojvodinu: Salaši, Etno Kuće, Vinski Podrumi, Čarde; Turistička organizacija Vojvodine: Novi Sad, Serbia, 2015.

53. Čajkanović, V. Studije iz Srpske Religije i Folklora; Srpska književna zadruga, BIGZ: Belgrade, Serbia, 1994.

54. Petrović, S. Srpska Mitologija. Sistem Srpske Mitologije, Knjiga I-V; Prosveta: Nis, Serbia, 1999. 
55. Radosavljević, U.; Lalović, K.; Milovanović Rodić, D. Key agencies networking for sustainable urban projects in Golubac \& Negotin. In Climate Change and the Built Environment: Policies and Practice in Scotland and Serbia; Pucar, M., Dimitrijević, B., Marić, I., Eds.; IAUS: Belgrade, Serbia; Glasgow Caledonian University: Glasgow, UK, 2013; pp. 472-490.

56. University of Belgrade, Faculty of Architecture. M9 Master Projekat. 2018. Available online: http: //www.arh.bg.ac.rs/wp-content/uploads/200809_docs/200809_DASA_9_2_29.pdf?pismo=lat (accessed on 23 May 2019).

57. Fainstein, S. New Directions in Planning Theory. Urban Affairs Rev. 2000, 35, 451-478. [CrossRef]

58. Radosavljević, U.; Mrđenović, T.; Pavić, J.; Krell, S. The Plan for Tourist Valorization of the Golubac Fortress; Faculty of Architecture: Belgrade, Serbia, 2010.

59. Radojčić, N. Zakon o Rudnicima Despota Stefana Lazarevića; Naučno Delo: Belgrade, Serbia, 1962.

60. UNESCO. Smederevo Fortress, UNESCO World Heritage Tentative List. 2010. Available online: https: //whc.unesco.org/en/tentativelists/5538/ (accessed on 25 January 2019).

61. University of Belgrade, Faculty of Architecture. Master Akademske Studije Integralni Urbanizam 2017/18-II godina. 2018. Available online: http://www.arh.bg.ac.rs/programi/master-akademske-studije-integralniurbanizam-201718/master-akademske-studije-integralni-urbanizam-201718-ii-godina/?pismo=lat (accessed on 1 April 2019).

62. Interreg. Interreg Danube Transnational Programme. 2019. Available online: http://www.interreg-danube. eu/approved-projects/danurb (accessed on 6 February 2019).

63. University of Belgrade, Faculty of Architecture. DANUrB Project: The First National DANUrB Workshop in Smederevo. 2018. Available online: http://www.arh.bg.ac.rs/en/2018/03/01/danurb-project-the-first-nationaldanurb-workshop-in-smederevo-26-february-2018/?pismo=lat (accessed on 17 April 2019).

64. University of Belgrade, Faculty of Architecture. Urban Management Course. 2018. Available online: http://www.arh.bg.ac.rs/wp-content/uploads/201819_programi/201819_dokumenti/1819_MASA/201819_ MASA_SVI_MODULI/201819_MASA-23040-03-IASA-59040-03-URBANI-MENADZMENT.pdf?pismo= lat (accessed on 8 February 2019).

65. University of Belgrade, Faculty of Architecture. DANUrB Project: The Second National DANUrB Workshop in Smederevo. 2018. Available online: http://www.arh.bg.ac.rs/en/2018/06/25/danurb-project-the-secondnational-danurb-workshop-in-smederevo-may-29-2018/ (accessed on 14 May 2019).

66. Nešković, J. Revitalizacija Spomenika Kulture; Faculty of Architecture: Belgrade, Serbia, 1986.

67. Djukić, A.; Kadar, B. (Eds.) Integrative Strategic Planning and Design for the Strengthening of Identity and Cultural Tourism in the Danube Cities—Smederevo; University of Belgrade, Faculty of Architecture: Belgrade, Serbia, 2018.

68. Leanza, P.M.; Porto, S.M.C.; Sapienza, V.; Cascone, S.M. A Heritage Interpretation-Based Itinerary to Enhance Tourist Use of Traditional Rural Buildings. Sustainability 2016, 8, 47. [CrossRef]

69. ICOMOS. The ICOMOS Charter on Cultural Routes. In Proceedings of the 16th General Assembly of ICOMOS, Québec, QC, Canada, 29 September-5 October 2008.

(C) 2019 by the authors. Licensee MDPI, Basel, Switzerland. This article is an open access article distributed under the terms and conditions of the Creative Commons Attribution (CC BY) license (http://creativecommons.org/licenses/by/4.0/). 